\title{
LA MEMORIA DE LOS SENDEROS ANDINOS. ENTRE HUACAS, DIABLOS, ÁNGELES Y DEMONIOS
}

\author{
THE MEMORY OF THE ANDEAN PATHWAYS. AMONGST HUACAS, \\ DEVILS, ANGELS AND DEMONS
}

\author{
Gonzalo Pimentela \& Alonso Barros ${ }^{B}$
}

Los geoglifos y petrogligos en el sendero entre Tamentica y Quebrada de Los Pintados (Guatacondo, Tarapacá), nos invitan a formular algunas hipótesis etnohistóricas y arqueológicas sobre cómo los pueblos prehispánicos andinos inscribían su política de la memoria en los senderos. Aunque con influjos europeos, las técnicas nemónicas y representativas andinas empleadas en su composición sirvieron para activar las geografías de la memoria y las huacas, en términos propiamente andinos, que los últimos constructores de geoglifos apenas alcanzaron a readaptar al canon estético y religioso del renacimiento europeo, legándonos la memoria de los senderos.

Palabras clave: Huaca, Geoglifos y petroglifos, Tunupa, Senderos de la Memoria, Conquista española.

The geoglyphs and petroglyphs on the trail between Tamentica and Quebrada de Los Pintados (Guatacondo Tarapacá), suggest a few ethno-historical and archaeological hypotheses on how in the Andes, the prehispanic politics of memory were written into pathways. Albeit with European influence, geoglyphs activate the geographies of memory and huacas in Andean terms, that the last geoglyph builders barely had the chance to readapt to the aesthetic and religious canons of European renaissance, leaving the memory of the path as their lasting bequest.

Keywords: Huaca, Geoglyphs, Petroglyphs, Tunupa, Paths of Memory, Spanish Conquest.
A la memoria de Thomas A. Abercrombie

(1951-2019).

"Incluso, en lo más hondo

llegué a imaginar senderos que nos podían devolver la mirada

y ayudarnos a escapar de lo

impuesto, de lo impostado,

para retomar un camino propio"

(Rivera Cusicanqui 2015: 244).

\section{INTRODUCCIÓN}

Los senderos en los Andes son más que simples sendas por las cuales se transita para conectar lugares y comunidades humanas. En el mundo aymara, thaki (sendero), es un fenómeno que articula una multitud de universos sociales, tales como las secuencias libatorias, las narrativas orales del pasado, los ciclos de canciones, las "carreras" de fiestas, los cargos religiosos y políticos. En efecto, thaki es la raíz semántica de un complejo

\footnotetext{
A Gonzalo Pimentel, Fundación Patrimonio Desierto de Atacama. Universidad de Tarapacá. E-mail: gpimentel@desiertoatacama.com
}

B Alonso Barros, Fundación Patrimonio Desierto de Atacama. E-mail: abarros@desiertoatacama.com 

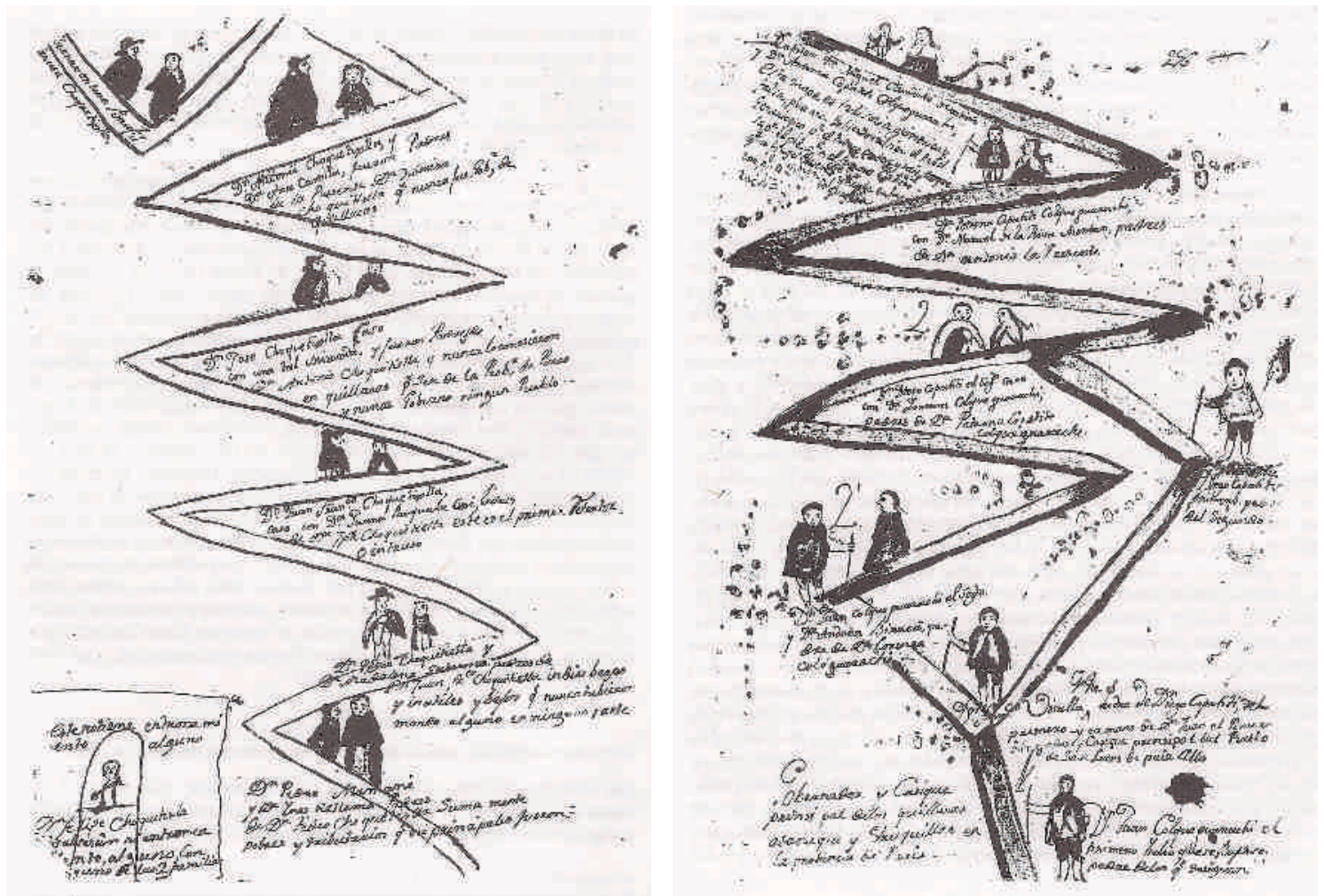

Figura 1. El árbol genealógico es representado como "camino genealógico" a principios del siglo XIx (1804). A la izquierda el de Colque Guarache y a la derecha, la familia Choqueticlla. Obsérvese en el último, en la esquina inferior izquierda, al mendigo Choqueticlla aislado y "sin camino" (Abercrombie 2006: 294-295). Figure 1. The family tree is represented as a "genealogical pathway" in the early 19th century (1804). With the Colque Guarache family on the left, and the Choqueticllas on the right. Observe in the lower left-hand corner of the latter, the beggar of Choqueticlla, alone and "with no pathway" (Abercrombie 2006: 294-295).

campo lingüístico que conecta los senderos físicos con los fundamentos ontológicos e históricos de la estructuración social y simbólica andina. Es tanto una técnica de producción de comunidad política, como una forma poética de narrativa que se funde con la historia y el territorio (geopoïesis). Por ejemplo, la expresión amtañ thaki (senderos de la memoria) se usa en referencia a las secuencias de chiallas que evocan lugares, en una suerte de viaje mental. Abercrombie los describe

como filas de actos seriados en movimiento que comienzan, subjetivamente, en un lugar y en un tiempo y acaban en otro. Se los puede concebir a todos como tipos de itinerarios o derroteros de viaje, $[\ldots]$ por lo que los seres humanos recuerdan y se dirigen a los dioses (Abercrombie 2006: 401 y 117). ${ }^{1}$

Este artículo explora cómo los senderos articulan la memoria histórica y geográfica andina, no en el sentido de la metáfora vial occidental (p. e., "el camino de Dios"), sino que en cuanto a la manifestación y actualización concreta de un sistema nemotécnico. Es en los senderos que se fraguan la historia, el pasado, las relaciones con los antepasados y con las deidades. Es lo que se puede reconocer, en parte, en la representación histórica de un "árbol genealógico" de 1804, en el que las familias principales, Colque Guarache y Choqueticlla, son mostradas como "caminos genealógicos" (fig. 1) (Abercrombie 2006: 294-295). Obsérvese en el "Camino genealógico" de los Choqueticlla a un mendigo que se encuentra aislado, doblemente encerrado y sin camino. En una sociedad como la andina tradicional, en la que todos los seres, ya sean humanos, animales o deidades deben tener su propio sendero, no tenerlo es equivalente a quedar afuera del mundo social, tal como el mendigo Choqueticlla.

Esta distintiva concepción los ubica en el otro extremo ontológico del Occidente medieval, donde la historia se encierra en la palabra escrita en los libros y 
se funda en el destino (ciudad/marka), mientras que en los Andes la historia, el pasado y el devenir se despliegan en los senderos, en el itinerario y en el viaje como recorrido (internodo/pampa) (Berenguer \& Pimentel 2017).

Damos un giro arqueológico a los "senderos de la memoria" para apostar por revelar, inversamente, la "memoria de los senderos". En efecto, las múltiples inscripciones a la vera de los senderos prehispánicos son expresiones materiales que marcaron y remarcan esa memoria inscrita, actualizando la historia durante el viaje y el recorrido ritual de hitos nemónicos, conforme a una ontología prehispánica que debe ser abordada e interpretada desde los propios sistemas andinos de representación.

El tramo del sendero que conecta Pica con Quillagua que aquí analizamos, entre Tamentica y Quebrada de Los Pintados, posee una de las mayores densidades de geoglifos que reconocemos en el desierto de Atacama. Entre ellos, un geoglifo realizado en la época colonial representa notablemente la conquista militar y espiritual española, configurando también una forma de insistencia historiográfica de corte propiamente andino.

\section{LOS GEOGLIFOS COMO SISTEMAS NEMOTÉCNICOS ANDINOS}

Se ha reconocido que los geoglifos en el desierto de Atacama se encuentran siempre a la vera de antiguas sendas transdesérticas y están normalmente emplazados en las laderas de los cerros, la gran mayoría siendo visibles desde los senderos. Corresponden a grandes figuras realizadas por despeje y/o adición del propio material superficial, generándose los motivos a partir del contraste entre el material superficial removido y la capa inmediatamente inferior. Las figuras superan generalmente los $10 \mathrm{~m}$ de largo y poseen una alta visibilidad (Núñez 1976, Briones 2006, Pimentel 2011, Gallardo et al. 2018).

Con una extensa tradición que remonta al menos al Período Formativo (ca. 1500/1000 AC-500/700 DC), se ha normalizado la idea de que los geoglifos eran señalizaciones de tránsito realizadas por los antiguos caravaneros (Núñez 1976: 179). Pero, entre ser mensajes destinados a señalizar las rutas caravaneras o tratarse de representaciones que dan cuenta de los imaginarios sociales prehispánicos, reconocemos que lo primero, aunque está presente, posee escasa relevancia frente al valor nemotécnico y la riqueza simbólica de su contenido.
Los geoglifos tardíos -ca. 900/1000-1540 DC, época de su mayor profusión en el norte de Chile-revelan una importante homogeneidad macroregional en cuanto a sus dimensiones, composición y temáticas. Fueron realizados principalmente mediante grandes despejes areales, con trazos rígidos, sintéticos y esquemáticos. Las figuras humanas, por ejemplo, aparecen representadas de frente, sin rasgos de animación, con trazos rectos y ataviadas con túnicas, tocados y portando varas o hachas, los que en esa época fueron elementos definitorios de la identidad del cuerpo social (Pimentel 2011).

Los geoglifos tardíos, por lo general no narran hechos o sucesos determinados, siendo sus temáticas más bien repetitivas y limitadas a actividades específicas, como el viaje en caravana de llamas. Las figuras se construían principalmente como agregados, a partir de la síntesis esquemática de cierto referente (p.e., imagen icónica humana) y de la abstracción conceptual (p.e., imágenes geométricas complejas), las que articulaban simbólicamente los sistemas de pertenencia y de diferenciación social primordiales y la cosmovisión andina. Tal es el caso de la figura de la chakana (rombo escalerado o "cruz andina"), uno de los diseños geométricos de tradición panandina más representados en los geoglifos del norte de Chile -a lo menos desde el 500 AC-, y que continuó en todas las épocas prehispánicas posteriores. Se puede observar que, hasta el presente, los pueblos andinos le asignan a esta figura importantes significados dentro de su cosmovisión ancestral (Milla 2011).

Las miles de figuras de geoglifos que se inscribieron asociadas a los antiguos sistemas de senderos prehispánicos en el desierto de Atacama, son sin duda, inscripciones de un alto contenido comunicacional, las que debemos intentar "leer" desde sus contextos y relaciones significativas.

\section{IMÁGENES PREHISPÁNICAS EN LA VÍA DE QUEBRADA DE LOS PINTADOS}

Como ya se indicaba, los antiguos senderos caravaneros que conectan Tamentica y Quillagua, cruzando la Quebrada de Los Pintados, concentran una de las mayores densidades de geoglifos conocidos en el desierto de Atacama, especialmente en el tramo inicial entre Tamentica y el sector sur de la Quebrada de Los Pintados (fig. 2). En los casi cuatro kilómetros que hay entre ambos sectores, se encuentra en promedio un geoglifo cada seis metros, dando una idea de la intensidad con que se 


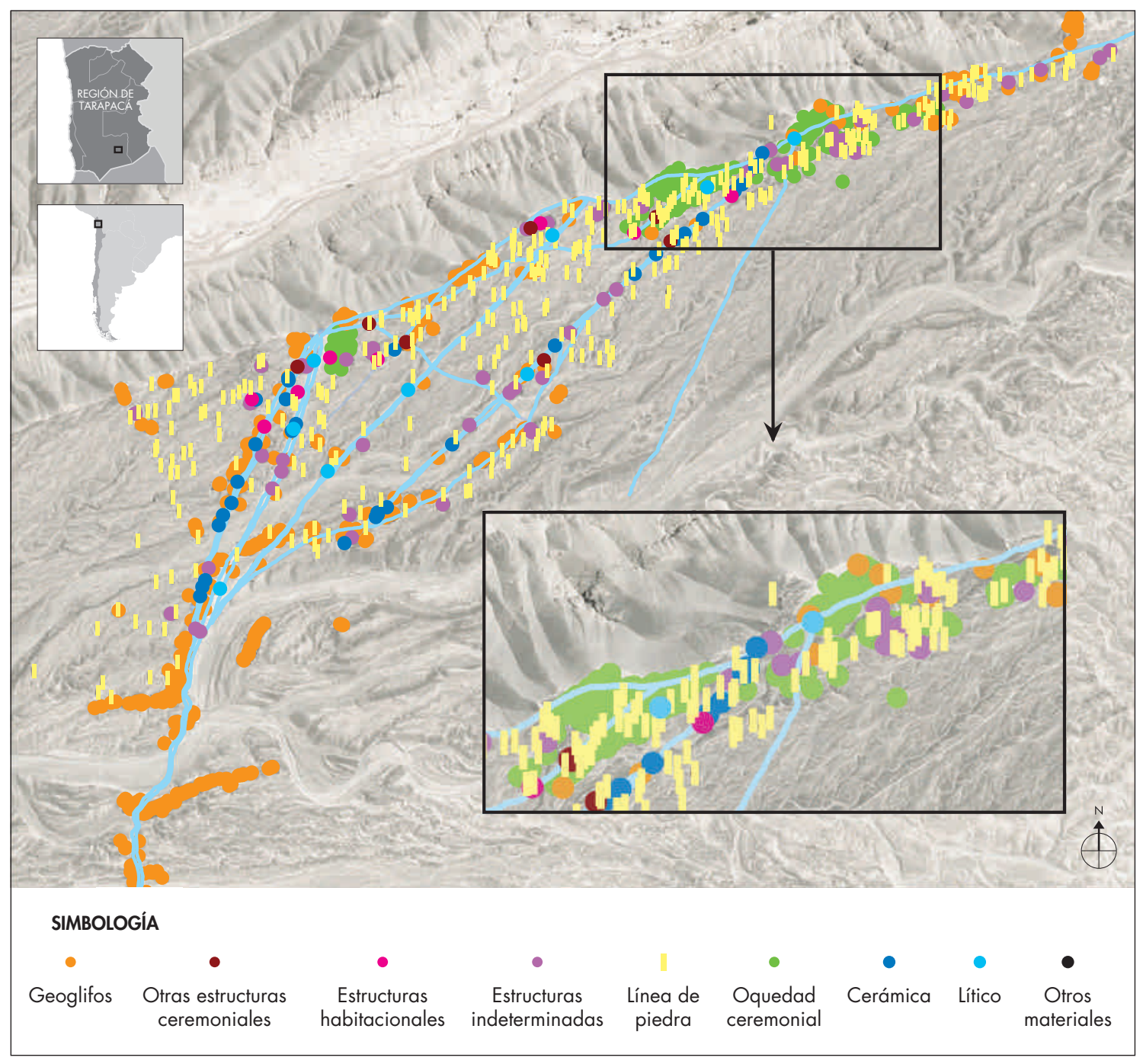

Figura 2. Mapa con los senderos, geoglifos, estructuras y materiales arqueológicas que se hallan en el tramo entre Tamentica (Quebrada de Huatacondo) y Quebrada de Los Pintados. Figure 2. Map showing paths, geoglyphs, structures, and archeological material discovered along the stretch between Tamentica (Quebrada de Huatacondo) and Quebrada de Los Pintados.

inscribieron las imágenes en el sector $(\mathrm{N}=649$ motivos de geoglifos, tabla 1). Si a esto agregamos las estructuras ( $\mathrm{N}=770$, mayoritariamente ceremoniales) y los bienes muebles presentes sobre los senderos, resulta que en este tramo vial no hay prácticamente ningún espacio sin evidencias arqueológicas. Los registros previamente realizados indican la presencia de más de mil figuras entre Tamentica y quebrada Honda, emplazadas tanto en las laderas como en las planicies desérticas (Clarkson \& Briones 2001). Este tramo destaca también por tener un gran número de geoglifos que se construyeron en el plano y no en las laderas de los cerros, lo que contrasta con el repertorio que se conoce para otros sectores donde predominan estos últimos (Briones et al. 2005, Valenzuela et al. 2011, Pimentel et al. 2017).

Las evidencias sugieren una primera intensificación en la construcción de geoglifos durante el Formativo Medio (ca. 500 AC-100/200 DC), tal como aquellas figuras "moteadas" que se pueden observar en el cerro de Challacollito desde la aldea de Guatacondo, a la par que florecían las aldeas próximas de Guatacondo y Ramaditas (Mostny 1970, Rivera 2005, Urbina et al. 2012, Uribe \& Vidal 2012, Cabello \& Gallardo 2014, Gallardo \& Cabello 2015). 
Tabla 1. Frecuencia de tipos de motivos de geoglifos en los sectores y sitios de la vía de Quebrada de Los Pintados. Table 1. Frequency of geoglyph motifs in sectors and sites on the Quebrada de Los Pintados trail.

\begin{tabular}{|c|c|c|c|c|c|c|}
\hline SECTOR SITIO & ANTROPOMORFO & ZOOMORFO & GEOMÉTRICO & FITOMORFO & INDETERMINADO & TOTAL \\
\hline Sector Alto Tamentica & 18 & 35 & 108 & 2 & 16 & 179 \\
\hline Quebrada Pintados Norte & 8 & 15 & 33 & 1 & 8 & 65 \\
\hline Sector Quebrada Pintados Alto Norte & 25 & 41 & 37 & - & 11 & 114 \\
\hline Quebrada Pintados Sur & 25 & 119 & 23 & - & 9 & 176 \\
\hline Sector Quebrada Pintados Alto Sur & 6 & 10 & 30 & - & 21 & 67 \\
\hline Quebrada Pintados Este & 18 & 14 & 6 & - & 8 & 46 \\
\hline Quebrada Pintados Este-1 & - & 2 & - & - & - & 2 \\
\hline Total & 100 & 236 & 237 & 3 & 73 & 649 \\
\hline
\end{tabular}

Partiendo desde el extremo norte del tramo estudiado, en Tamentica, una escena grabada da cuenta de dos personajes de perfil, cada uno con una vara, en lo que parece ser el acto de estar golpeando entre los dos a un tercer personaje, también de perfil, pero más pequeño, encorvado y con un bastón (fig. 3). Inmediatamente hacia la izquierda del trío, se observa una balsa de dos cuerpos, sobre la cual se puede observar un personaje con una vara o un remo, como dirigiéndose al poniente, al Océano Pacífico.

Esta narrativa primaria evoca fuertemente el relato andino de Tunupa. Este verdadero mito de origen andino cuenta que, en algún tiempo prehispánico impreciso, llegó al poblado de Carabuco (lago Titicaca) un anciano predicador de pequeña estatura, con un báculo y pronunciada giba, llamado Tunupa (o Thunupa, Tonopa, Talapaca, Tuapaca, entre otros) (Ponce 1969, Gisbert 1980, Urbano 1988, Bouysse-Cassagne 1997, Chacama \& Espinoza 1997, Abercrombie 1998, Wachtel 2001, Medinacelli 2012). De fiesta y borrachera, la gente desató su ira contra la inesperada visita, dándole palos al anciano hasta darlo por muerto. Amarrado Tunupa a una balsa de totora es lanzado al lago Titicaca, donde los fuertes vientos empujan la embarcación hacia el extremo sur-oeste del lago, dando inicio así al "viaje acuático" del héroe cultural, que rompe el borde del lago con la proa, creando el río Desaguadero que lo transporta hasta el lago Poopó y el salar de Uyuni (el volcán Tunupa dominando el sector intersalar), y luego continúa, adentrándose por un paso transandino hasta alcanzar un nuevo río, que lo lleva finalmente hasta el Océano Pacífico, en el que desaparece. ${ }^{2}$

Este relato propone sugerentes niveles de lectura, pero aquí nos detendremos en aspectos centrales relativos a la comprensión de la nemotecnia toponímica compartida en diversos mitos de origen andinos, cuyos cerros, ríos y senderos se enhebran con la memoria geográfica, actualizada en cada lugar, en cada viaje. El mito de Tunupa conecta así, acuáticamente, el lago Titicaca con el lago Poopó, pasando luego por el salar de Uyuni para retomar finalmente aguas que bajan hasta el Océano Pacífico. Tunupa configura a su paso una gigantesca divisoria de aguas, que está inscrita en la memoria geográfica y compromete más de $1000 \mathrm{~km}$ lineales. De esta manera, el mito sobre su viaje no es solo metafórico, sino que es cosmogónico, y vive en la geografía mediante ritos de memoria asociados a cada lugar significativo, en un derrotero sagrado y consecuentemente venerado. ${ }^{3}$

El caso es que la única cuenca a la que pudo referirse al viaje de Tunupa hacia el mar Pacífico es la del río Loa, uno de cuyos nacimientos está en el volcán Miño, a unos $70 \mathrm{~km}$ al suroeste del salar de Uyuni. El río más septentrional que conforma la cuenca del Río Loa es el de Guatacondo, cuyas nacientes brotan al oeste del salar de Uyuni, en la vertiente occidental de la Cordillera de los Andes que separa ambas macro-cuencas. Las aguas del río Guatacondo no llegan hoy más allá de Tamentica, por lo que no se le considera de tipo exorreico, pero si retrocedemos al Período Formativo Temprano y Medio 
(ca. 1500/1000 AC-100/200 DC), se puede asegurar que el río Guatacondo regaba hasta la pampa, donde las aldeas de Guatacondo y Ramaditas estaban en pleno desarrollo y se cultivaban las planicies aledañas mediante el uso y canalización del río. Las aguas de Guatacondo luego fluyen hacia el salar de Llamara, que desagua en el río Loa Inferior por la Quebrada Amarga o Cua Cua, en el quiebre final que hace el río hacia el mar, a unos $30 \mathrm{~km}$ de la costa Pacífico.

Sabemos que Tunupa fue reapropiado por la narrativa evangelizadora de la Iglesia Católica como Santo Tomás o San Bartolomé. ${ }^{4}$ Pues bien, tal como en la escena en Tamentica (fig. 3), en uno los frescos de la Iglesia de Carabuco (fig. 4), vemos a San Bartolomé martirizado por dos personajes que lo golpean. Simétricamente, en el cuadro siguiente el santo "que suelta el agua" es amarrado a una balsa y lanzado al lago Titicaca. El petroglifo de Tamentica y la balsa navegando hacia el Pacífico, forman una síntesis narrativa idéntica a la que inscribió el mito de Tunupa en la iglesia de Carabuco. El río Guatacondo pudo ser, de esta manera, la inscripción del curso del viaje acuático de Tunupa, y Tamentica uno de los puntos donde los viajeros del desierto actualizaron ritualmente la memoria andina del mito fundacional y su héroe cultural Tunupa. Cada viaje siendo así una consagración de la geografía en su memoria y viceversa. Entre los pueblos andinos, si a un mito se le agregan los ritos de sacralización, ambos, mito y rito sacro, se expanden y multiplican en la memoria geográfica, grabada reiteradamente por miles de antepasados que por ahí transitaron reviviendo el amt'añ thaki de Tunupa. Las creencias tradicionales y rituales de viaje de evocación andina solo empiezan a decaer tras el impacto de las ontologías conquistadoras e inquisidoras de la Europa Medieval, a las que les resultó intolerable esta confusión entre mito y realidad, salvo en términos cristológicos y por más que sean igualmente "idolátricos" (Bernand \& Gruzinski 1993).

¿Fue inscrito el mito del viaje acuático de Tunupa en los bloques graníticos de Tamentica durante el Período Formativo, hace 2500 a 3000 años atrás? (fig. 3). Como sea, estas hipótesis interpretativas del gran parteaguas andino permiten acercarnos a los mitos en los geoglifos y grabados como expresiones profundas de la memoria andina.

Retomando el curso arqueológico, la construcción de geoglifos aumentó considerablemente durante el Período Intermedio Tardío (ca. 900/1000-1450 DC).
Los estilos y temáticas se hicieron cada vez más simples y homogéneos, caracterizados por el agregado de figuras aisladas y con escasas escenas, misma tendencia iconográfica que continúa en el Período Tardío o Inka (ca. 1450-1535 DC) (figs. 5 y 6).

Un gran zig-zag destaca en la parte central de la ladera norte de la Quebrada de Los Pintados (N=65 geoglifos), análogo a los "caminos genealógicos" de la figura 1 (fig. 5). A la derecha del rombo escalerado -de una gran simetría-, se yergue una figura antropomorfa de frente, rígida, de tocado semilunar y túnica rectangular, cuyo interior es un emblema colectivo característico del Período Intermedio Tardío, que se aprecia también en un peto de cuero procedente del Loa Medio (Berenguer 2004a: 182, figs. 3, 9; Nielsen 2007: 24, fig. 19).

Por otra parte, las dos figuras humanas centrales del sitio Quebrada de los Pintados Norte-1 poseen túnica rectangular con diseño de diagonales cruzadas y círculos concéntricos (fig. 6), considerado un indicador del Período Tardío (Montt 2005). Ambas esbozan un tocado semilunar y llevan una vara o hacha en una mano, mientras que la otra pareciera sostener una cabeza cercenada. Al antropomorfo representado a la derecha "en negativo" le atribuimos una fecha de construcción más temprana.

\section{ESCENAS DE LA CONQUISTA EUROPEA}

La Conquista europea y su evangelización militarizada entró en los Andes el año 1532, impactando y conmoviendo todo el sustrato de creencias andinas y transformándolo para siempre. Las nuevas técnicas nemónicas como la escritura y el libro (la biblia), junto a los sistemas de registro administrativo-jurídicos europeos, fueron paulatinamente reabsorbiendo y eclipsando las memorias tradicionalmente guardadas y narradas en los quipus, los queros, los senderos, la toponimia, los textiles y los geoglifos, entre otros. ${ }^{5}$ Tres escenas de geoglifos de la Quebrada de los Pintados son de épocas coloniales, lo que nos habla de una cierta resistencia -o más bien insistencia-frente al avallasamiento cultural, mediante las nemotecnias visuales andinas:

1) El sitio Quebrada de Los Pintados Alto Norte-1 (fig. 7) fue escenificado en un plano a escasos metros de los senderos y está compuesto por cuatro figuras humanas en perspectiva y movimiento, cargando juntas una viga 


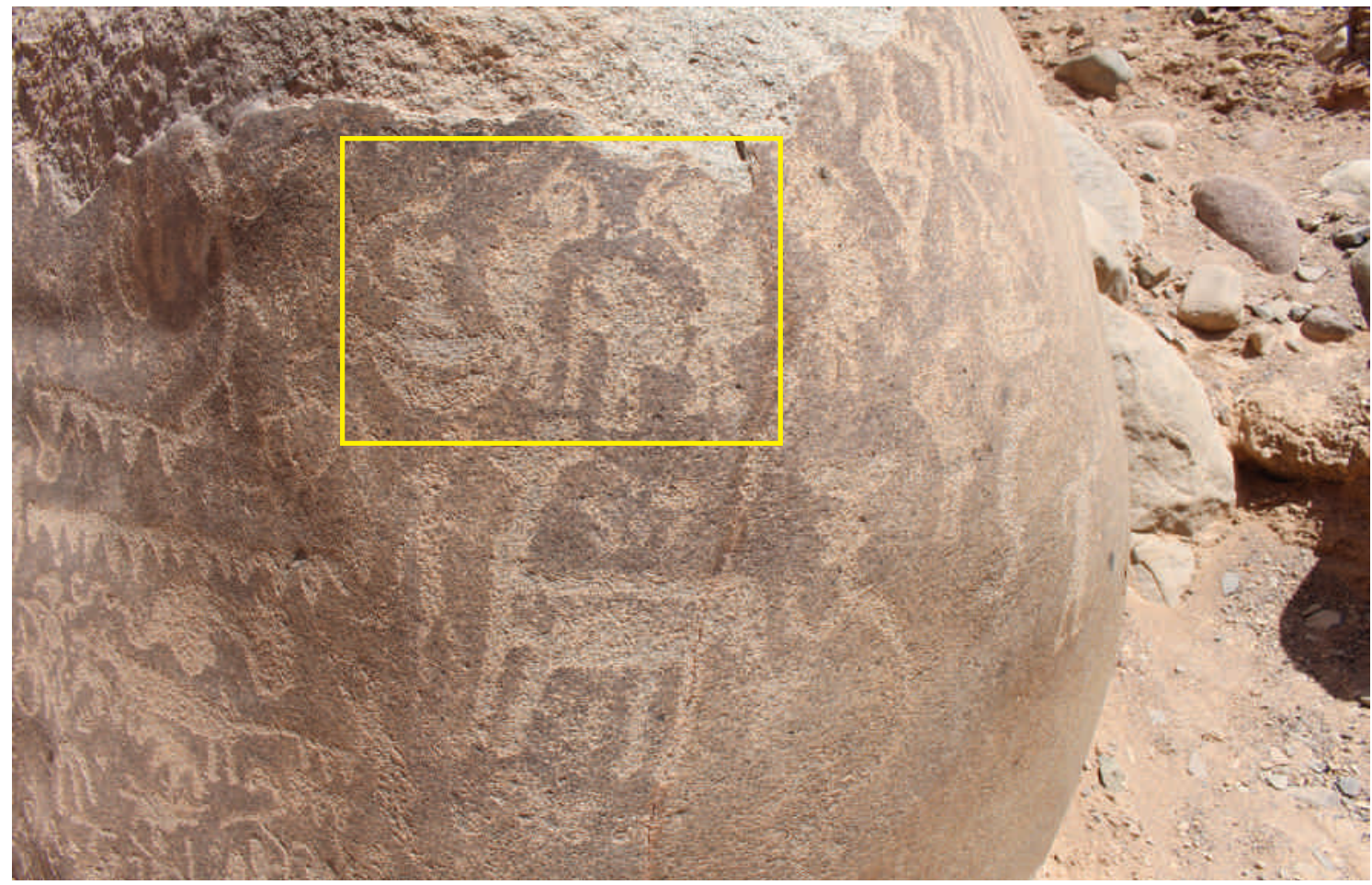

Figura 3. Grabados formativos del sitio de Tamentica. En la parte superior y central de la escena, dos personajes fueron representados golpeando a otro más pequeño en el centro $(\mathrm{h}=10 \mathrm{~cm})$, mientras una balsa y una figura humana se orientan al Oceáno Pacífico. Figure 3. Formative engravings at the Tamentica site. In the upper center of the scene, two figures are represented beating another, smaller one in the middle $(h=10 \mathrm{~cm})$, while a raft and human figure face the Pacific ocean.

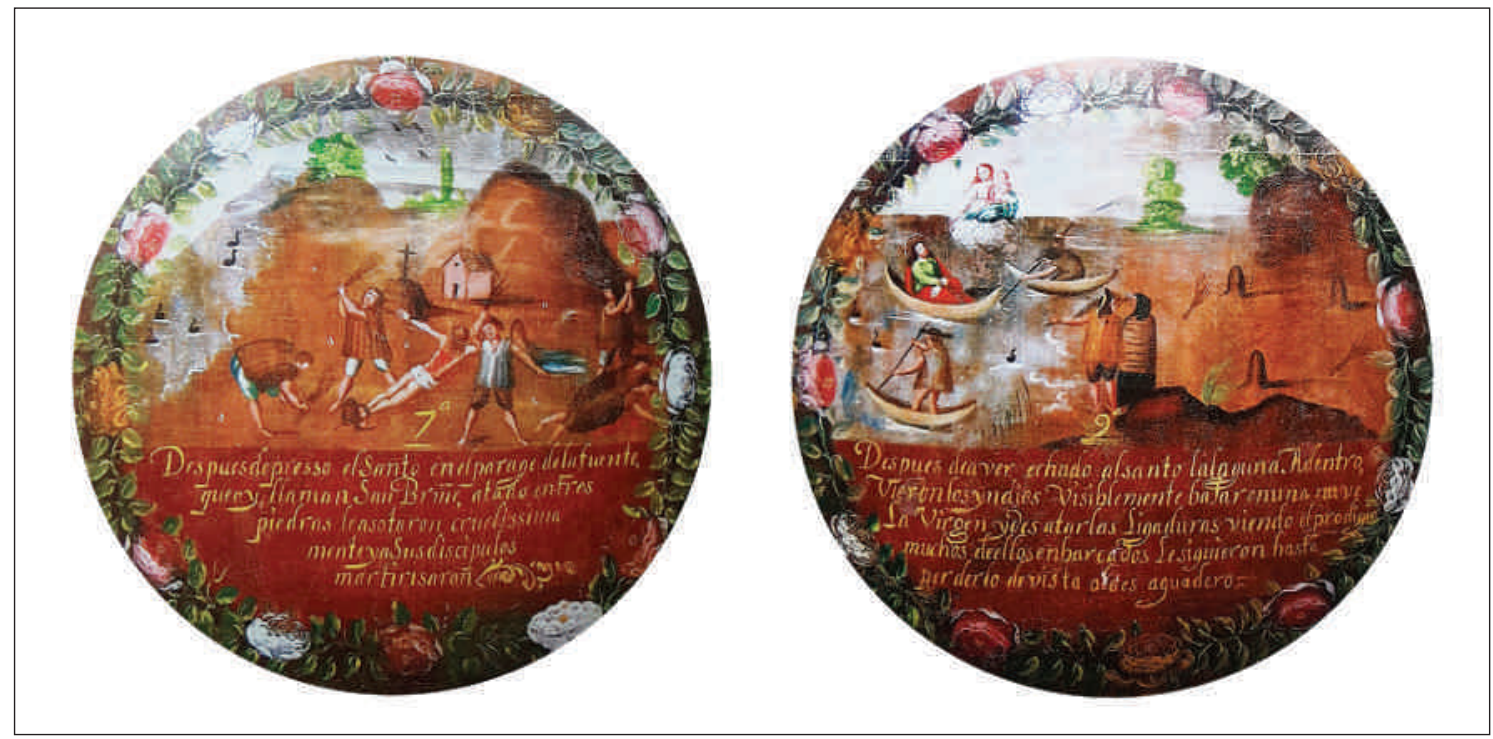

Figura 4. Pinturas de la iglesia de Carabuco. La imagen izquierda representa el martirio de San Bartolomé y la derecha, cuando es atado a una balsa y arrojado al Titicaca, en evidente alusión a Tunupa (tomadas de Siracusano 2010: 133). Figure 4. Paintings in the Church of Carabuco. The image on the left represents the martyring of San Bartolomé, and that on the right, when he is tied to a raft and thrown into Titicaca, in an obvious allusion to Tunupa (from Siracusano 2010:133). 

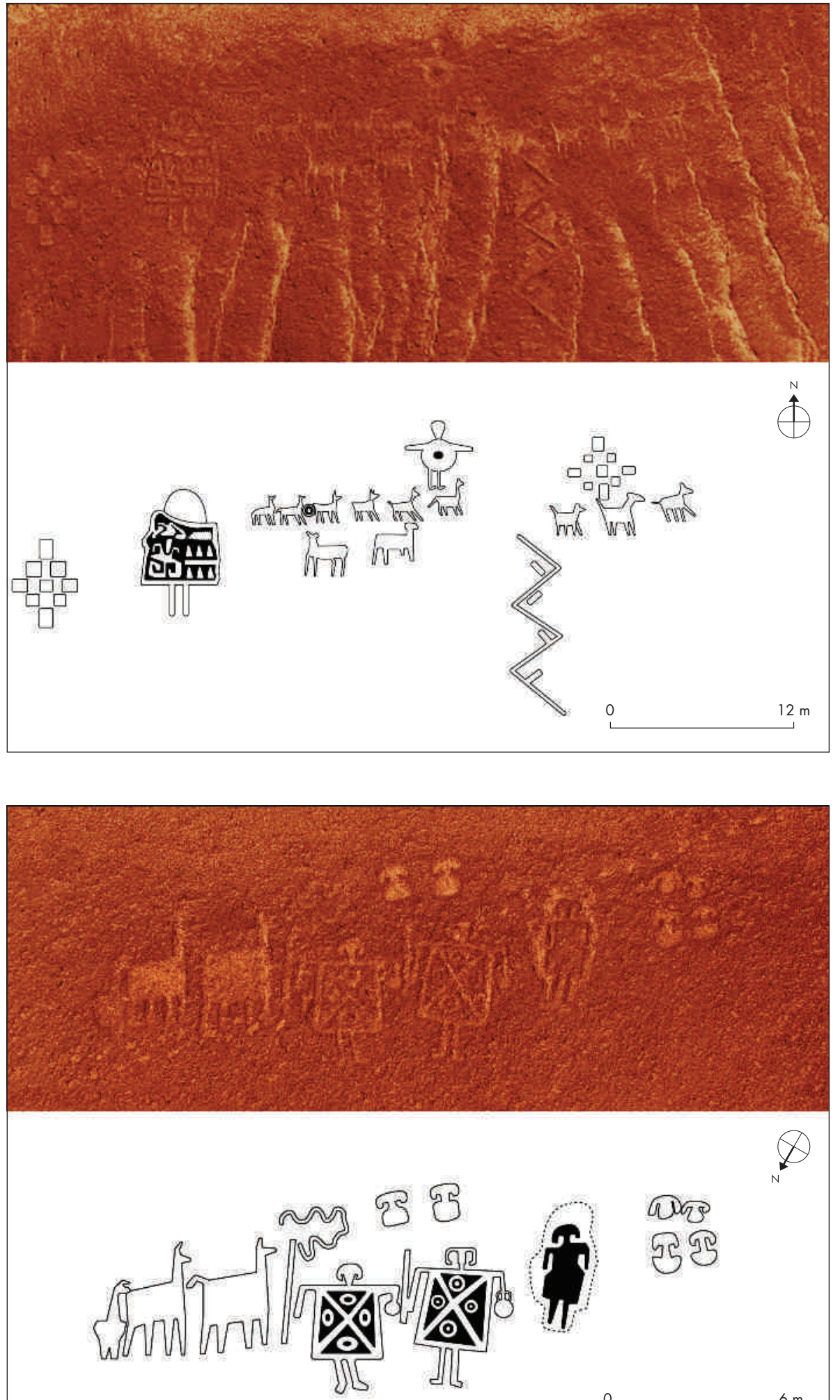

0 $6 \mathrm{~m}$
Figura 5. Fotogrametría aérea y dibujo sitio Quebrada de Los Pintados Norte (dibujo: Fundación Desierto de Atacama). Figure 5. Aerial photogrammetry and sketch, Quebrada de Los Pintados North site (drawing: Fundación Desierto de Atacama).

Figura 6. Fotogrametría y dibujo sitio Quebrada de Los Pintados Alto Norte. Los geoglifos fueron pisoteados, dejando en evidencia su gran fragilidad (dibujo: Fundación Desierto de Atacama).

Figure 6. Aerial photogrammetry and sketch, Quebrada de Los Pintados Alto North site. The geoglyphs were stomped upon, displaying their great fragility (drawing: Fundación Desierto de Atacama). 


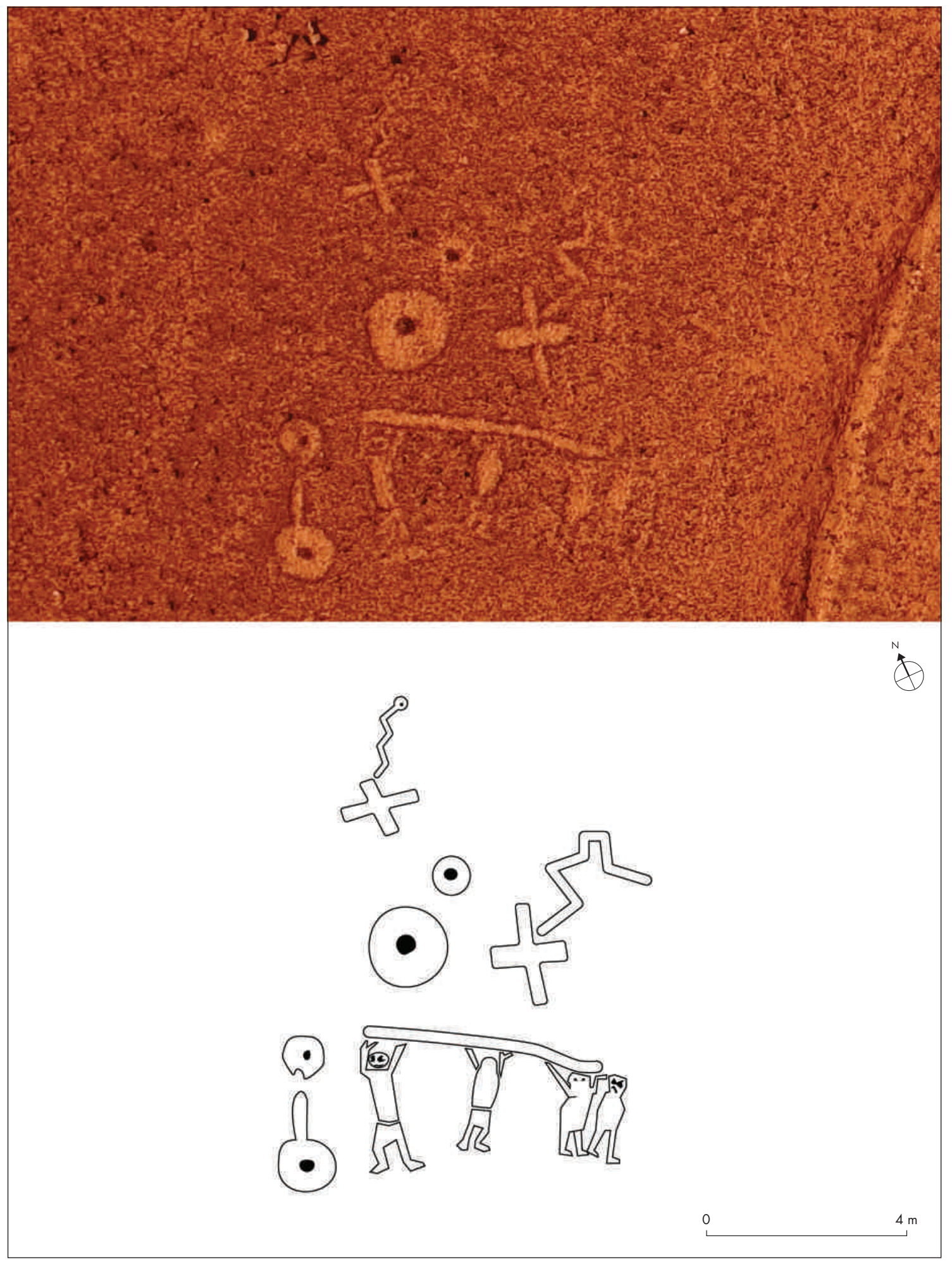

Figura 7. Fotogrametría y dibujo Quebrada de Los Pintados Alto Norte (en plano), (dibujo: Fundación Desierto de Atacama). Figure 7. Aerial photogrammetry and sketch, Quebrada de Los Pintados Alto Norte (situated on the plain), (drawing: Fundación Desierto de Atacama). 


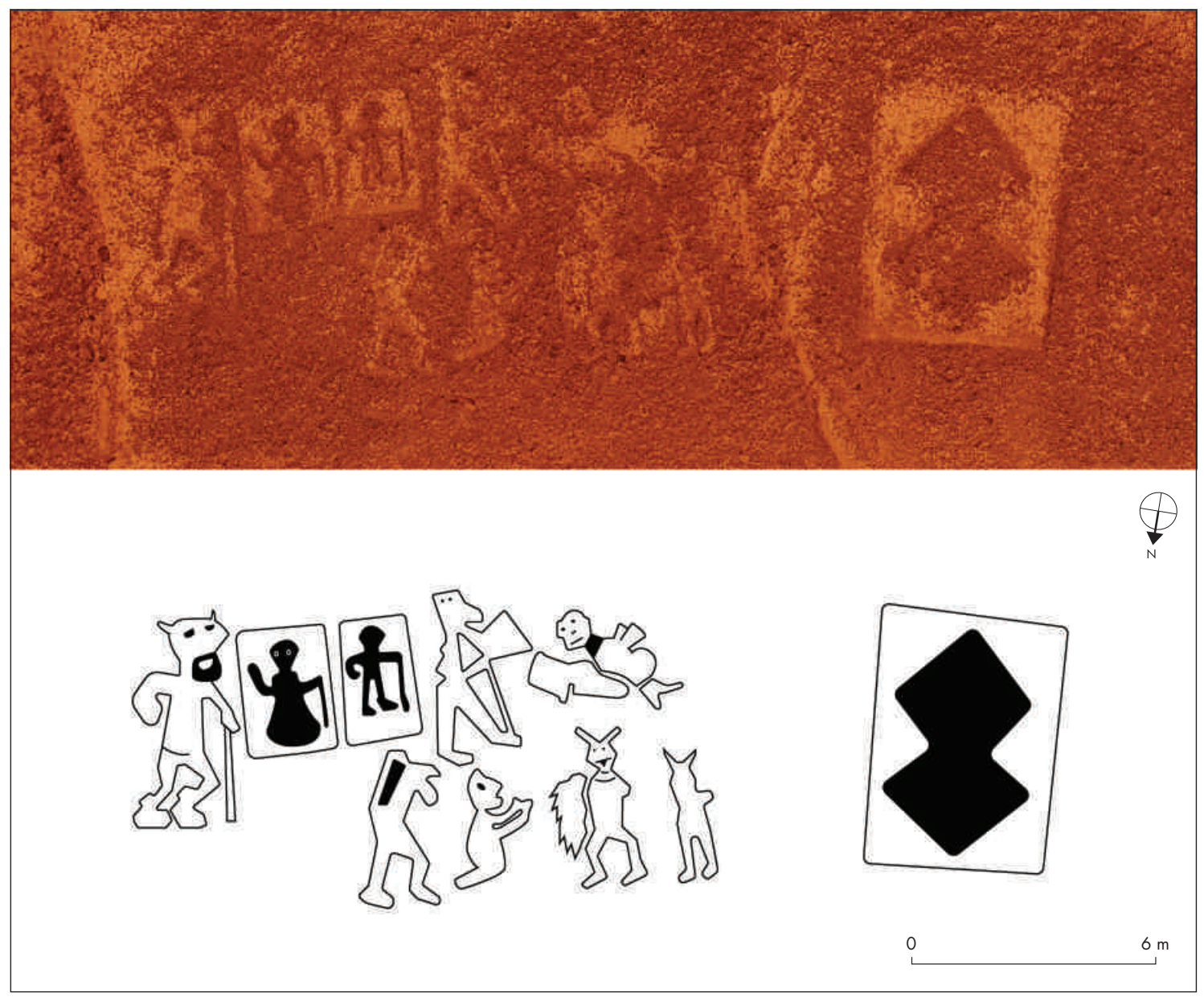

Figura 8. Fotogrametría y dibujo del sitio Quebrada de Los Pintados Sur (dibujo: Fundación Desierto de Atacama). Figure 8. Aerial photogrammetry and sketch of the Quebrada de Los Pintados Sur site (drawing: Fundación Desierto de Atacama).

o vara larga. La figura central tiene los brazos arriba y piernas semiflectadas en posición de ir cargando el madero, extenuada, con un realismo figurativo que combina el estilo renacentista europeo con las técnicas y soportes geográficos andinos tradicionales. La relación entre las cruces y los círculos de punto central ha sido considerada como uno de los registros coloniales más tempranos en los Andes, por lo que esta escena parecería dar cuenta de la primera época de la Colonia (Martínez 2009, Martínez \& Arenas 2009, Arenas \& Odone 2015).

2) Otro conjunto de geoglifos se ubica al este del sitio Quebrada de los Pintados Sur (fig. 8). De entre los 176 motivos de geoglifos identificados en la extensa ladera, destaca la escena en que una persona arrodillada de perfil tiene las manos juntas a la altura del pecho, como rezando, entremedio de varias figuras humanas, con la mirada entornada hacia arriba, posiblemente en dirección a otros seres alados dispuestos en posición horizontal, que bien podrían representar a ángeles de la tradición católica. La figura "humana" que se ve en el extremo izquierdo de la imagen podría ser la representación del "diablo" católico y "tiw" surandino, aunque este tipo de motivos y sus características los retomaremos más adelante.

Ya que la escena corresponde a la adoración (rezo) de seres angelicales, es probable que fuera construida en una fecha posterior a la de la figura 7, posiblemente a fines del siglo Xvir o del XviII, tiempo en que se masifican las imágenes de ángeles y seres alados en los murales de las iglesias andinas (Gisbert 1998, Corti et al. 2013, Guzmán et al. 2017). 
3) El último conjunto colonial está en la Quebrada de los Pintados Este y corresponde a una monumental escena de geoglifos de $70 \mathrm{~m}$ de largo que representa la irrupción ibérica al desierto de Atacama durante el siglo XVI (figs. 9, 10 y 11). De un valor etnohistórico y artístico excepcional, esta notable escenificación resulta de la aplicación de técnicas visuales ancestrales con las que los pueblos andinos inscribían su memoria geográfíca y su cosmovisión, articulados en torno a conceptos claves como ayllu, pachamama, yanantin, apu o mallku (Platt 1980, Urton 1981, Rostworowski 1983, Martínez 1983, Murra et al. 1986, Barros 1997).

Orientada de norte a sur, la escena del viaje representa a seres ajenos al universo andino prehispánico, de un modo altamente figurativo, combinando una estética y contenidos europeos con el repertorio andino tradicional. Así, junto a las caravanas de llamas, aparecen animales desconocidos hasta ese entonces para los habitantes del desierto, como caballos y burros. La figura central del conquistador español, por su parte, ostenta los característicos zaragüelles (o pantalón bombacho) de su época, morrión emplumado (o casco), espada y alabarda, objetos de factura colonial temprana. Posiblemente sea estos parte de los últimos geoglifos que realizaron los indígenas sobrevivientes de las "dos conquistas", la militar y la espiritual. ${ }^{6}$

Desde atrás hacia delante, en el sentido del viaje de la escena, se reconoce primero una caravana de seis llamas (Lama glama), representadas con cuatro patas, cuerpo areal y con cola en punta hacia arriba. En la llama de mayor tamaño $(h=5,4 \mathrm{~m}$ ) se le resaltaron los ojos y la boca. Es una serie de camélidos ordenada de menor a mayor tamaño, los que luego vuelven a "achicarse", dándole perspectiva a la caravana, además de movimiento y profundidad, la cual es una técnica prehispánica de larga tradición. En el extremo izquierdo de la imagen, casi encima del primer camélido a la izquierda, se reconoce otro cuadrúpedo que podría tratarse de un felino, dados su extensa cola y cuerpo alargado. Fue posiblemente representado al acecho por su ubicación superior y en diagonal al eje de la caravana de llamas.

Retomando nuestro sendero hacia el sur, aparece otro ser con algo difuso saliendo de su hocico cuadrangular. Correspondería quizás a un animal fantástico del mundo Occidental y Oriental, el dragón, motivo que se encontraba ampliamente incorporado dentro del imaginario visual paneuropeo (p.e., en la leyenda católica de San Jorge o San Jordi y el dragón), así como en distintos soportes coloniales andinos (Hecht 2004: 50, figs. 48 y 49$)$.

La figura del conquistador está representada de frente; esto es, bajo la misma modalidad de los geoglifos tardíos. Mientras a la mayoría de los demás antropomorfos de la escena se les representó de perfil y sin mayores atributos exógenos, al Conquistador, el personaje central y de mayores dimensiones $(\mathrm{h}=9,6 \mathrm{~m})$, quien sostiene una alabarda en su lado derecho $(7,3 \mathrm{~m}$ de largo), se le dota de atributos como zaragüelles, morrión emplumado, cinturón, cartuchera, botas, escudo y espada. La especificidad de la figura y su posición central sugieren que pueda tratarse del "descubridor" de Chile, Diego de Almagro, quien regresó por estos senderos en 1536, retornando al Perú, o del Conquistador de Chile, Pedro de Valdivia, quien viajó precisamente por esta vía en el año 1540 en su recorrido al valle central de Chile. Volveremos sobre estas hipótesis.

El caso es que la construcción de la figura del Conquistador combina el arte tardío prehispánico (humanos de frente, rígidos y ataviados con vestimentas, tocados, armas) y la introducción del renacentismo católico en los Andes, con un estilo que transita entre lo medieval y lo barroco, y en una dirección completamente contraria a la que venía desarrollándose la historia visual andina prehispánica. Conseguir efectos renacentistas mediante el soporte gravilloso de las laderas es una hazaña artística en sí, porque de un plano bidimensional se logra levantar una escena tridimensional, un verdadero trompe-loeuil. La composición de la escena que prosigue hacia el sur es propiamente europea, en la que el orden de las figuras está dotado de un eje de dirección, en diagonal y en perspectiva, de modo de generar efectos de distancia, profundidad de campo y movimiento.

Continúa la escena con un jinete sobre un caballo, del que se le trazan solo las patas traseras $(\mathrm{h}=2,8 \mathrm{~m})$, un recurso iconográfico muy utilizado en la Europa de la época para generar perspectiva y reforzar el sentido de distancia y dinamismo. De la figura se desprende una especie de propulsor (¿ballesta?) apuntando hacia un motivo zoomorfo de gran tamaño ( $h=3,8 \mathrm{~m}$ ), de cabeza cornamentada y entornada para atrás. La posición de las cuatro extremidades y su mirada en clara huida, sugieren una escena de caza, en la que un segundo antropomorfo con zaragüelles enfrenta la presa con una lanza u otra arma similar, tratándose probablemente de un español. La figura zoomorfa representa a una Taruca (Hippocamelus antisensis), único animal con 


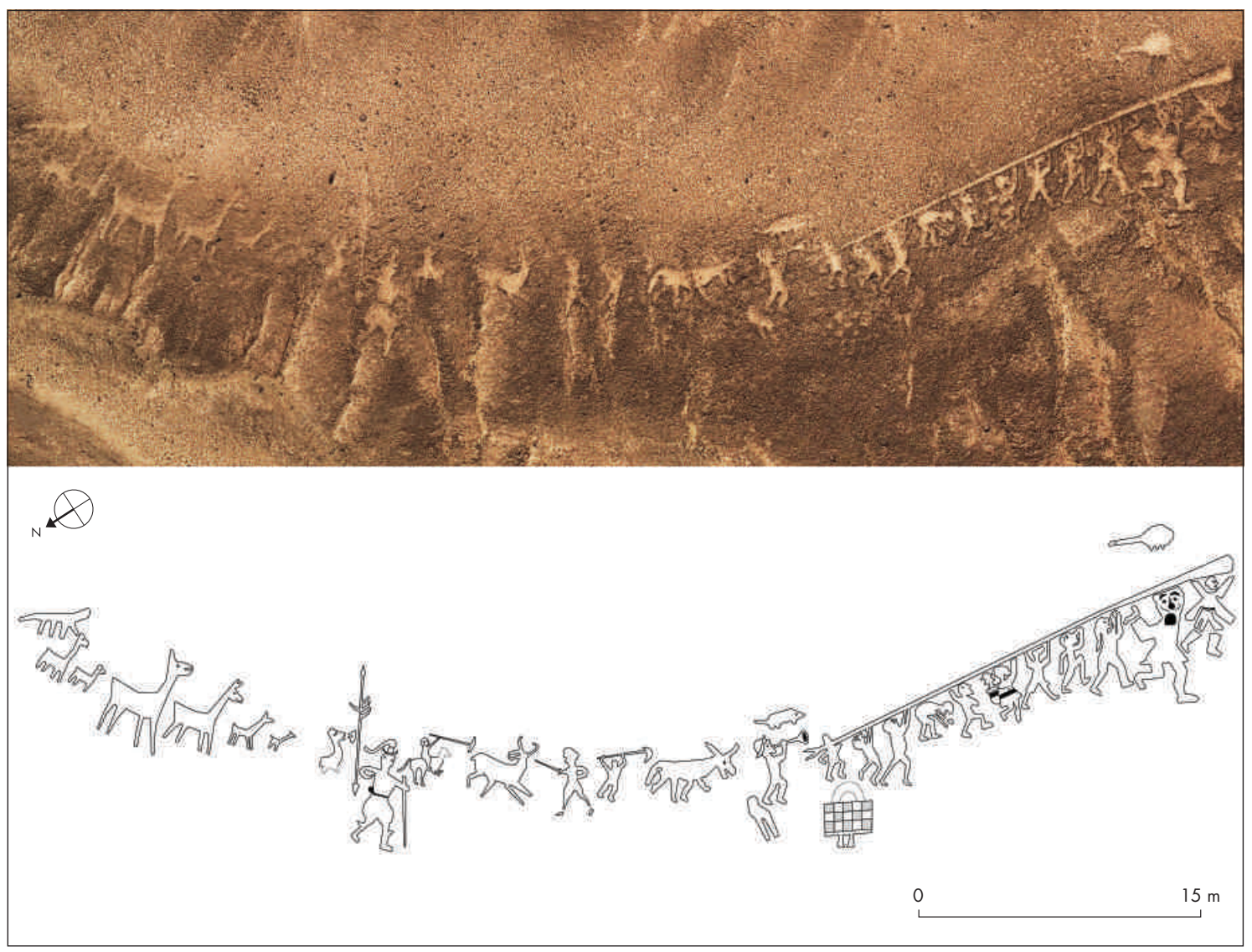

Figura 9. Fotogrametría y dibujo de escena colonial compleja del sitio Quebrada de Los Pintados Este (dibujo: Fundación Desierto de Atacama). Figure 9. Photogrammetry and sketch of a complex Colonial-era scene at the Quebrada de Los Pintados Este site (drawing: Fundación Desierto de Atacama).

astas endémico a estas regiones. ${ }^{8}$ De la figura humana precedente $(\mathrm{h}=2,8 \mathrm{~m})$ se desprende un segundo elemento propulsor dirigido hacia otra figura zoomorfa $(\mathrm{h}=3,2$ $\mathrm{m})$. Esta última, por sus rasgos distintivos, como orejas, cola y cuerpo, corresponde a un burro (Equus africanus asinus), cuyas extremidades son representadas en animación, caminando hacia el sur.

Aunque integrada al conjunto, la secuencia que sigue constituye una escena aparte que no debe perderse de vista en su composición particular (fig. 9). Siguiendo el trayecto del viaje, se aprecia primero una figura antropomorfa $(\mathrm{h}=3,8 \mathrm{~m})$ con casco, ojos, boca y bigotes, piernas semiflectadas, en acto de estar caminando y tocando una trompeta o chirimía como se le denominaba en la colonia. La trompeta apunta hacia otras 12 figuras de personajes que se asocian a una línea de 25 metros que asemeja un largo madero. Puede verse que esta larga línea comienza en forma de delgada horqueta (como las de las trompetas traversas) y se va ensanchando poco a poco hacia el sur. ${ }^{9}$

Las figuras humanas parecen estar cargando el "madero" o estar amarrados a éste. Las tres primeras figuras tienen una pierna semiflectada y la otra estirada, con el cuerpo levemente inclinado hacia atrás y los brazos arriba tocando el "madero", con una gestualidad que denota sobreesfuerzo. Adelante, una cuarta figura antropomorfa es representada doblada, la espalda en paralelo al "madero" y con la boca abierta, al parecer vomitando, transmitiendo así el geoglifo un sobrecogedor efecto de agotamiento físico. Le sigue una quinta figura humana $(\mathrm{h}=2,8 \mathrm{~m}$ ) que tiene un adminículo unido al hombro, el que podría corresponder a un arcabuz. El hecho de no tener los brazos extendidos hacia arriba sugiere que el personaje podría estar cumpliendo la función de "vigilante" en la escena. La figura siguiente parece representar una mujer con falda que mira al 
"vigilante", tiene la pierna derecha flectada, la cabeza entornada hacia atrás y carga un niño con sombrero en el brazo derecho, tocando el "madero" con el izquierdo.

El séptimo motivo antropomorfo $(\mathrm{h}=3 \mathrm{~m})$ es representado con pantalón corto y piernas abiertas, en mangas de camisa, con los brazos levantados unidos al "madero" y la cabeza inclinada hacia adelante. La figura humana siguiente $(\mathrm{h}=2,9 \mathrm{~m})$ tiene una pierna semiflectada hacia delante y la otra extendida hacia atrás, lleva un brazo abajo y el otro levantado. Como no toca el "madero", hipotetizamos que podría tratarse de otro "vigilante".

La novena figura posee las piernas semiflectadas y los brazos parecen estar atados al "madero" ( $\mathrm{h}=4,2 \mathrm{~m}$ ). Al rostro se le delinearon el ojo derecho, mentón, nariz y boca mediante una línea angulada hacia arriba, y el pelo largo con unas líneas gruesas que le caen sobre la espalda.

Dos figuras centrales cierran esta gran escena colonial: el Diablo y el Arcángel San Miguel. Primero se halla el Diablo, de grandes dimensiones $(\mathrm{h}=6,1 \mathrm{~m})$, y luego, a su derecha el Arcángel ( $h=4,7 \mathrm{~m}$ ) (figs. 10 y 11). Esta disposición espacial refleja la distinción teológica católica según la cual el Diablo está a la izquierda, marcando la entrada al inframundo infernal, mientras que a la derecha y en el centro se ubica San Miguel, con la función de juzgar y separar a justos de pecadores.

Por su tamaño, la figura del Diablo es solo comparable con la del Conquistador. Es representado con grandes fauces, pequeña cola y patas anchas que parecen representaciones de pezuñas o garras. También se le marcaron los ojos, nariz y grandes cejas (figs. 10 y 11). En su extremidad superior derecha sostiene un elemento con forma de cuerno y, además, se le insinúan dos cuernos en la cabeza que se yuxtaponen al "madero".

Estos elementos permiten identificar que se trata de la figura del Diablo tal como se representaba en la época colonial y la que se puede observar en una pintura proveniente de Cuzco (1682), con la representación del demonio inspirada en el fauno, mezcla de humano (cuerpo, brazos, cabeza) y de macho cabrío (cuernos, orejas puntiagudas, pezuñas y cola. Fig 12).

Al Arcángel San Miguel se le puede reconocer en los rasgos característicos con que se le representaba en el imaginario europeo medieval: un ser alado calzado con botas de caña alta, que viste un faldellín de estilo romano y sostiene un pie más arriba que el otro, tal como en las conocidas imágenes históricas en las que San Miguel es mostrado pisando al demonio (fig. 13).
Aunque en el geoglifo estén representados uno al lado del otro, se ve que el Arcángel tiene su bota derecha sobre el muslo izquierdo del Diablo. Que San Miguel Arcángel lidere la narrativa del Juicio Final en esta "caravana colonial" en dirección al poblado de Quillagua (cuyo santo patrono es precisamente San Miguel Arcángel), nos ilustra en parte el contexto de extirpación de idolatrías de lugares sacros andinos (huacas) por los conquistadores europeos. La representación del Diablo en oposición al Arcángel San Miguel narra los motivos principales de la ideología y el dogma católico del Juicio Final (Bouysse-Cassagne 2008). Con todo, la escena fue construida por viajeros en un registro de memoria y reproducción cultural que utiliza su propia técnica ancestral, eran arquitectos del mundo andino en un espacio significativo prehispánico. Tal como en los geoglifos tradicionales, estos cultores andinos se esforzaron, quizás por última vez, en escribir su historia, esta vez con motivos coloniales, pero manteniendo los cánones y técnicas visuales andinos, en una única e irrepetible mezcla de estéticas occidentales y andinas. ${ }^{10}$

En términos iconográficos, destaca inequívocamente el estilo renacentista: realismo, gestualidad exacerbada, efectos de dinamismo y acción en las figuras, sorprendentes detalles corporales, multiplicidad de escenas y planos, perspectiva y profundidad, dan cuenta de la temprana e intensa integración de los modos de hacer artísticos europeos en el mundo andino. En varias iglesias coloniales, existen reproducciones del grabado de Thomassin. Por ejemplo, en las Postrimerías cristianas de la Iglesia de Carabuco, incluyendo la escena del Juicio Final (fig. 14). Esta última pintura (1684) es una copia fiel $y$ a todo color del infierno de Thomassin. En la escena superior central, un grupo de indígenas con su vestimenta tradicional (túnicas, mantas, tupu) parecen estar realizando rituales ancestrales, sosteniendo dos queros orientados hacia lo alto con presencia de música con instrumentos de viento (quena) y tambores. El Diablo indígena cierra el relato teológico identificando estos elementos tradicionales con el pasado prehispánico, el pecado y la culpa, legitimando simultáneamente el castigo, sellando con esto el imaginario ideológico y visual de los demonios y el infierno occidental católico. La "paleta del espanto" que sintetiza magistralmente Siracusano (2010) fue parte de las estrategias visuales utilizadas por la Corona española para lograr la "colonización del imaginario" andino (véase también Gisbert \& de Mesa 2010, Rodríguez \& Etchelecu 2010). 


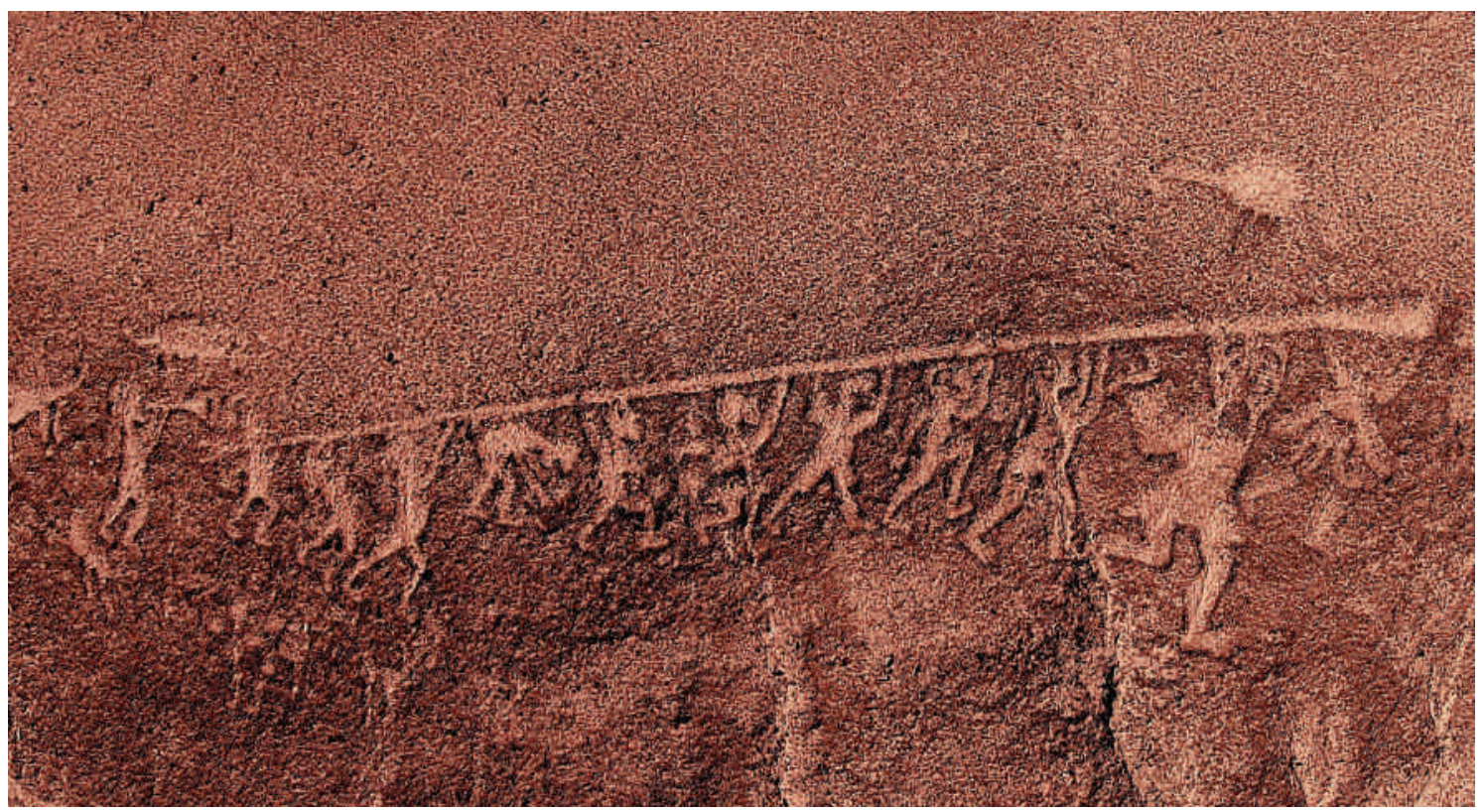

Figura 10. Detalle de la escena final. Fotografía aérea utilizando un dron, sitio Quebrada Los Pintados Este. Figure 10. Detail of the final scene. Aerial drone photography, Quebrada Los Pintados Este.

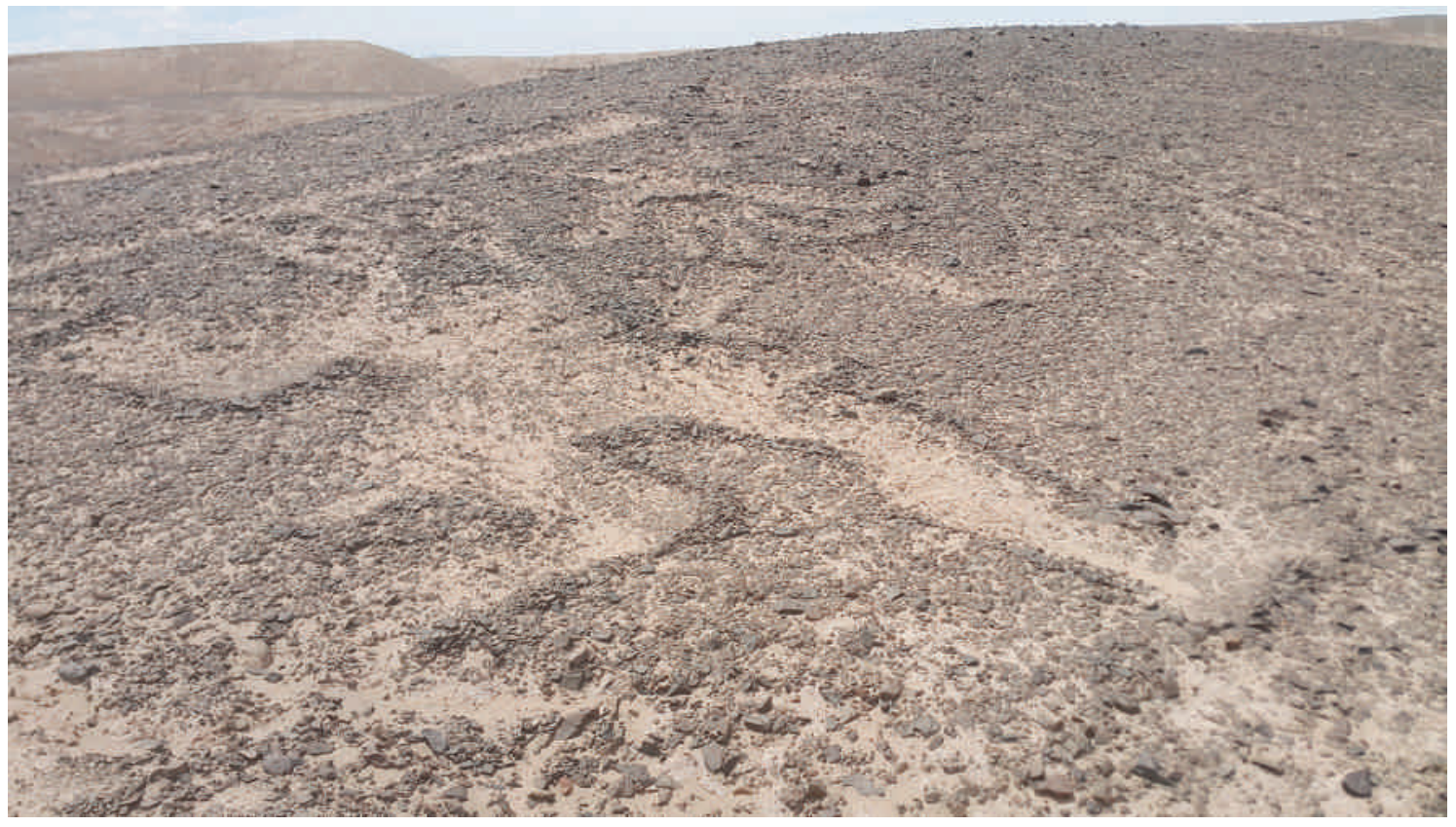

Figura 11. Vista desde el suelo. En primer plano, la figura mayor que representa al Diablo y a la derecha, la representación del Arcángel San Miguel en el centro superior de la imagen. Figure 11. Seen at ground level, in the foreground the larger figure is the Devil, and on the right, in the upper center of the image, is the archangel St. Michael. 


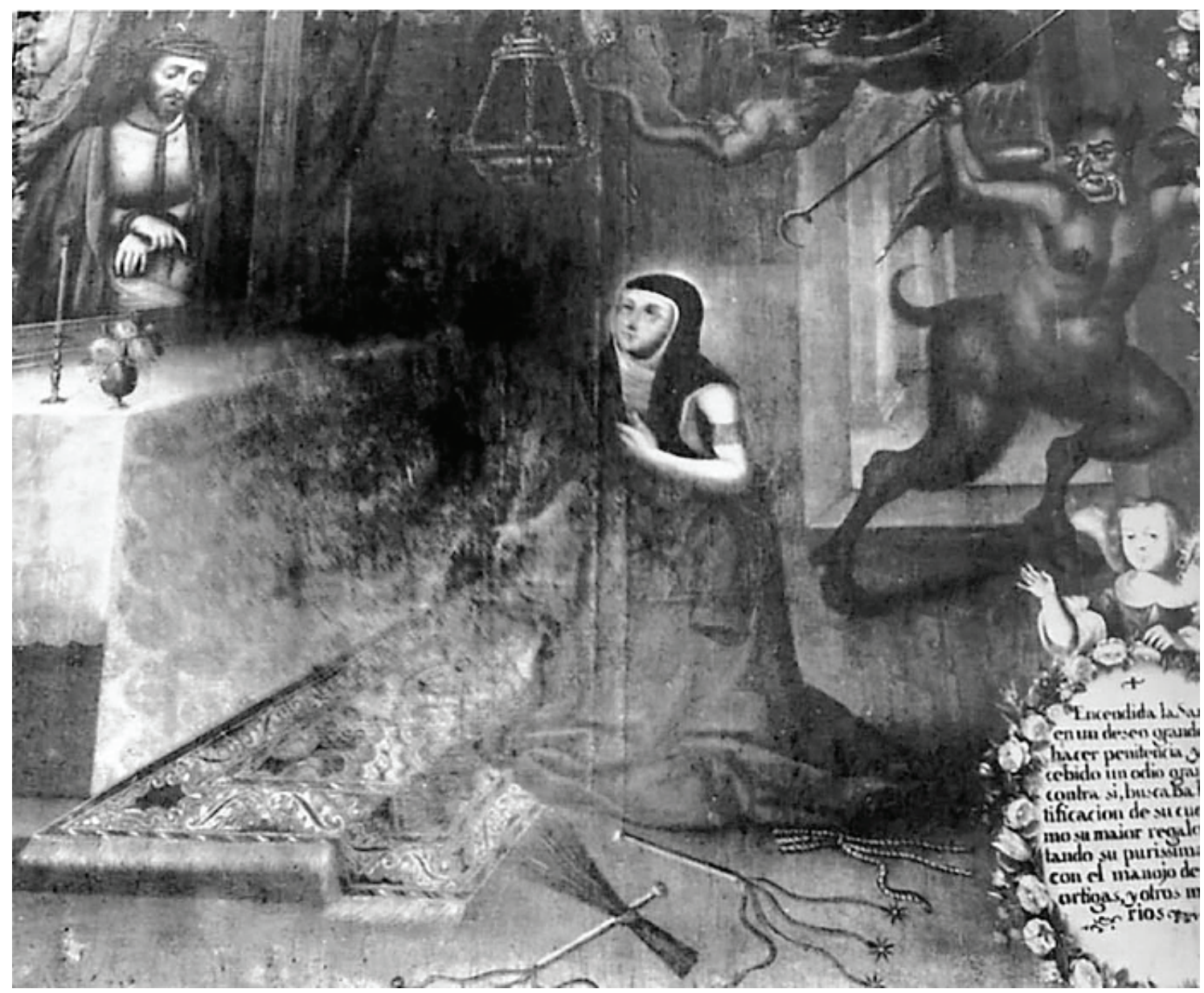

Figura 12. Pintura del año 1682 de la serie Santa Teresa en penitencia, de la Iglesia del Convento Santa Teresa de Cuzco. Autoría de José Espinoza de los Monteros (tomado de Mebold 1987: 78). Figure 12. Painting from 1682, from the series Santa Teresa en Penetencia, from the church of the Convent Santa Teresa de Cuzco, painted by José Espinoza de los Monteros (from Mebold 1987:78).

¿En qué época fue realizada esta gran escena del geoglifo colonial?, ¿fue elaborada en un solo momento o es el resultado de distintos eventos constructivos? La imagen del Conquistador con los característicos pantalones bombachos, indica que podría tratarse de un geoglifo colonial temprano (siglo xvI). Sin embargo, el pantalón y camisa corta que lleva una de las figuras que van bajo el madero y la falda que porta la mujer (ausencia de unku) en los motivos coloniales, nos sugieren, por el contrario, que partes de la escena pueden haber sido inscritas el siglo XVII o XVIII (véase al respecto Martínez \& Arenas 2015, Money 1983). De haber sido construido en estas fechas mas tardías, la representación de la figura del Conquistador podría tratarse de una rememoración posterior, como la que se puede observar en algunas obras pictoricas en iglesias altiplánicas del siglo XVII, $o$ incluso en ciertas representaciones teatrales actuales en los Andes.

Con todo, cabe la posibilidad de que la obra haya sido realizada en distintos momentos constructivos y no de una sola vez. Así parece sugerirlo también la representación de la caravana de llamas, cuyos trazos se corresponden con estilos de los períodos tardíos. Mientras la figura del Conquistador hace referencia al siglo XVI, la vestimenta de los antropomorfos que se asocian al madero los vinculan con el siglo Xvir en adelante, lo mismo que la presencia de divinidades occidentales, como el Arcángel San Miguel y el Diablo, cuyas imágenes se popularizan en el repertorio de los murales de las iglesisas andinas del siglo xvir y xviII. 


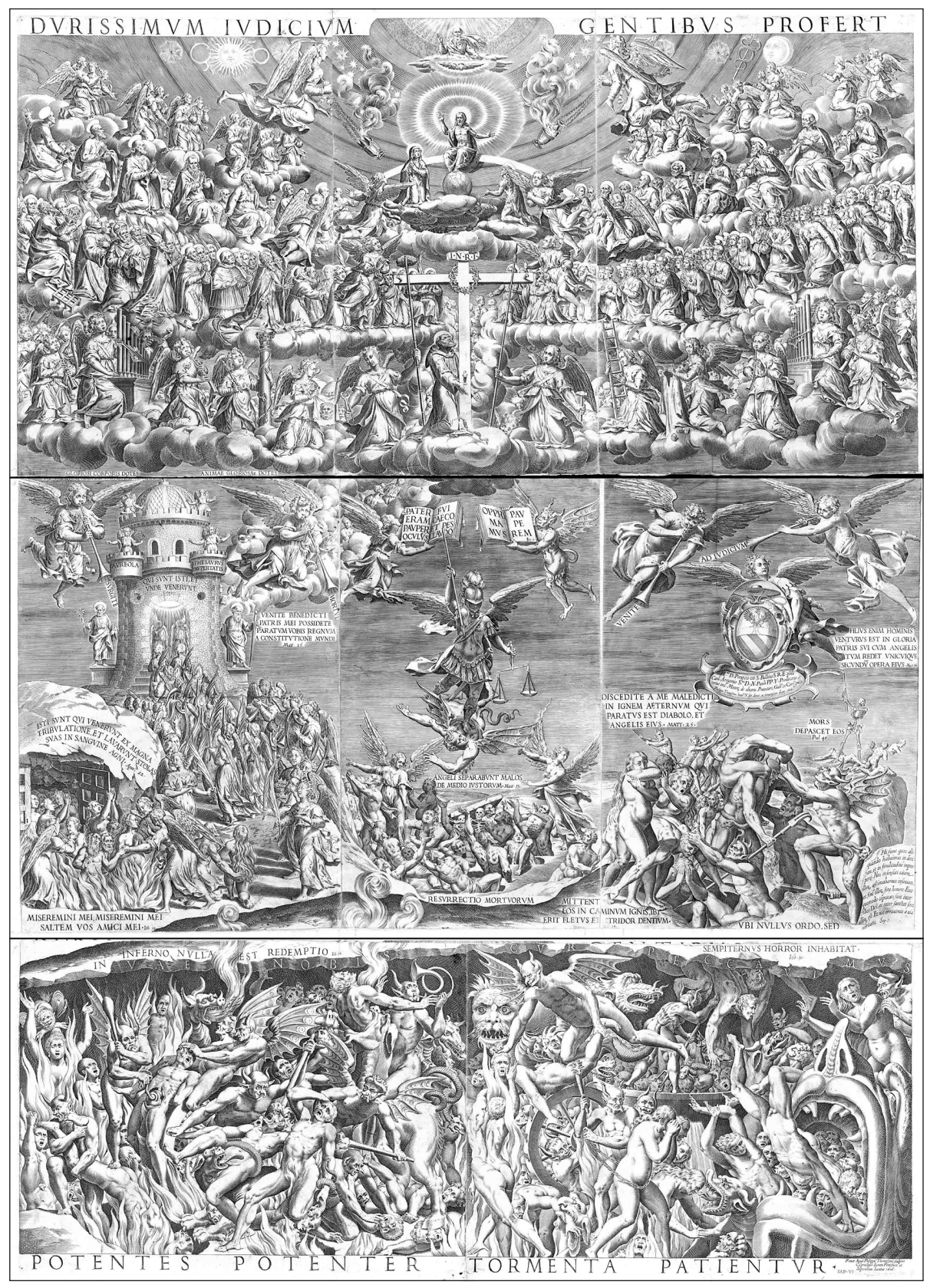

Figura 13. Estampa del Juicio Final (1600) por Philippe Thomassin. Este grabado fue ampliamente difunfido en las pinturas de las iglesias andinas y de América (imagen tomada del catálogo 939A del Project for the Engraved Sources of Spanish Colonial Art (PESSCA, www.colonialart.org [consultado: 12-11-2018]). Al centro, San Miguel Arcángel, a su izquierda diablos y demonios que marcan la entrada al inframundo. A su derecha, la salvación y el "reino del cielo". Compárese con el Juicio Final representado en la iglesia de Carabuco, lago Titicaca. Figure 13. Print of the Last Judgment (1600) by Philippe Thomassin. This engraving was used in the paintings of many colonial-era churches in the Americas, including the Andes (image taken from catalogue 939A of the Project for the Engraved Sources of Spanish Colonial Art (PESSCA www.colonialart.org [retrieved: 12-11-2018]). At the center of the image is the archangel St. Michael, to his left are devils and demons marking the entry to the underworld. On his right is salvation, the "kingdom of heaven." Compare it to the Last Judgment in the church of Carabuco, on Lake Titicaca. 


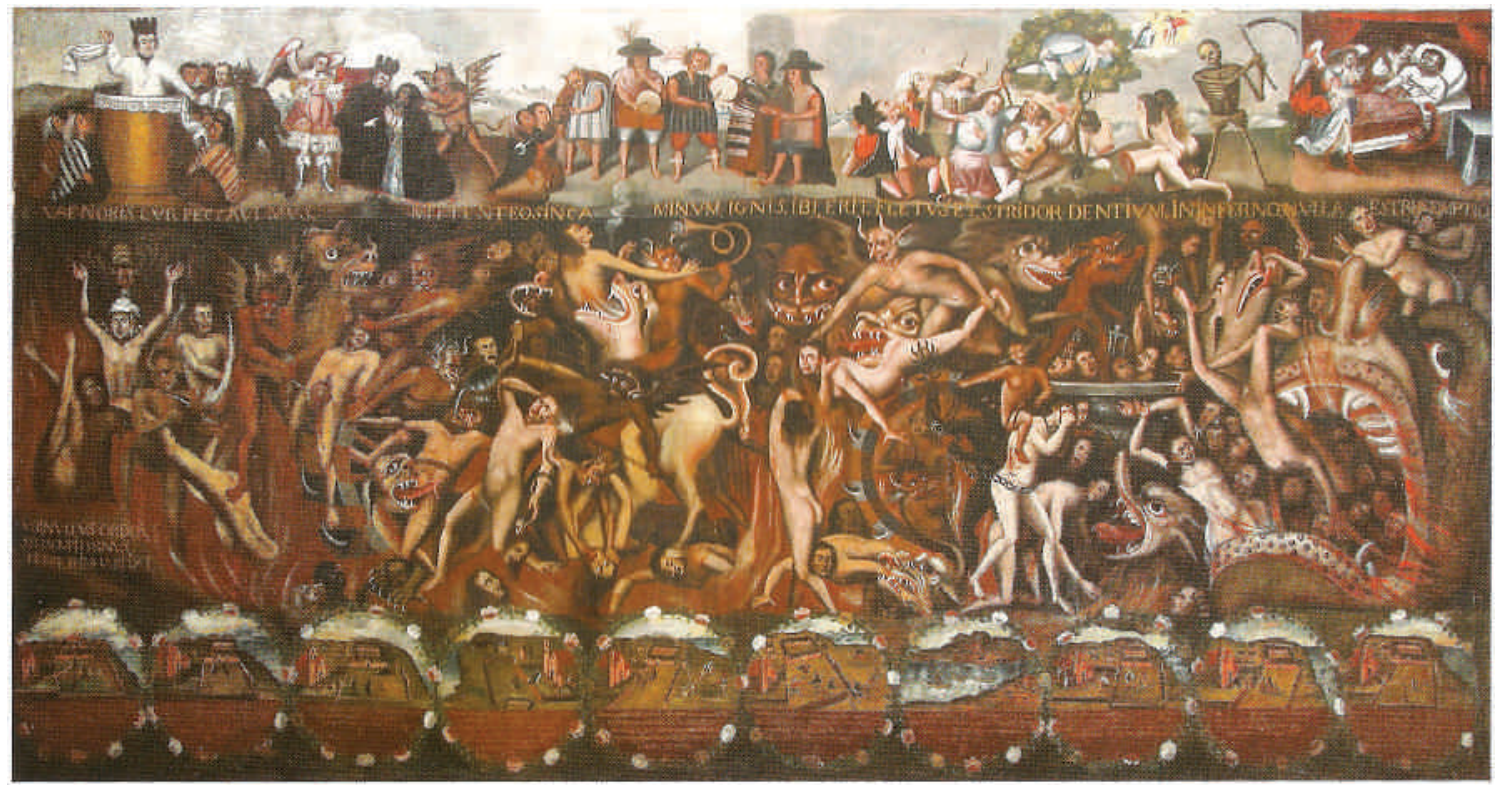

Figura 14. El lienzo del Juicio Final de la iglesia de Carabuco, lago Titicaca (1684), se inspira en el grabado de Thomassin (fig. 13) (tomado de Siracusano 2010: 125). Figure 14. The canvas of the Last Judgement found in the church of Carabuco, on Lake Titicaca (1684) is inspired by the engraving of Thomassin (fig. 13) (from Siracusano 2010: 125).

En efecto, es en las pinturas de los muros de las iglesias altoandinas donde encontramos que la escena analizada posee sus principales referentes iconográficos y composicionales.

Para realizar la escena del geoglifo colonial, sin embargo, no hubo un modelo o impreso en papel para copiar o calcar, lo que le da al conjunto un carácter absolutamente singular en cuanto documento visual histórico. Las expresiones y gestos de los "cuerpos retorcidos" en el geoglifo colonial, nos remiten al imaginario católico de un viaje necesariamente destinado a enfrentarse a la muerte: "a la beatitud del paraíso o a las penas y el espanto del infierno".

El geoglifo referido se diferencia notablemente de otros registros del arte rupestre colonial en los Andes, caracterizados por una limitada y repetitiva variedad de figuras y temáticas representadas, como son las inscripciones de cruces cristianas, jinetes, iglesias y sombreros de copa. ${ }^{11}$ Por ejemplo, el sitio Alero Pintoscayoc 1 (Humahuaca, Noroeste Argentino), describe una escena similar donde se representó de perfil y en pintura negra un jinete a caballo de grandes proporciones, a los que anteceden tres antropomorfos a pie atados del cuello, lo que fue interpretado como "marcha de prisioneros" (Hernández Llosa 2006: 24, fig. 15).
El caso es que, figuras como el arcángel San Miguel, el Diablo y el Conquistador, no son comunes en el repertorio visual rupestre ni en los queros coloniales. El inédito detallismo, logrado mediante la técnica de geoglifos, denota un grado mayor de dificultad y maestría, junto a un acabado dominio del arte religioso europeo y colonial. Este gran fresco rupestre nos revela "la mano" de un experimentado artista andino, con alguna especialización evidente en las técnicas de pintura de murales y lienzos de las iglesias coloniales. Solo un artista de proveniencia andina podría haber dominado tanto la técnica tradicional de los geoglifos, como el conocimiento de estas icónicas imagénes católicas y formas renacentistas, con suficiente maestría como para traspasar estas últimas a un soporte a cielo abierto, tridimensional y generando un alto contraste con la monocromía general del desierto. No conocemos otro geoglifo en el desierto de Atacama elaborado con tanto detallismo de gestualidades, animación y elementos corporales (boca, ojos, cejas, nariz). No estamos ante una mera copia de imágenes impuestas por la Iglesia Católica y la estética renacentista europea, sino que ante un monumental despliegue de virtuosismo andino que se apropia de íconos europeos y las técnicas renacentistas, para remarcar al mismo tiempo creencias prehispánicas. 
La principal relevancia está en el particular bricolage de lo andino y lo europeo logrado en el lugar. Su significación socio-espacial tradicional, el tipo de soporte, la técnica de geoglifos, parte de la composición representacional, de la estructura narrativa de la escena y ciertas temáticas expresadas, como la caravana de llamas y el tipo de trazado del Conquistador, representado con su vestimenta, rígido y de frente, son expresiones y técnicas andinas del Período Tardío. Con este geoglifo, el artista andino-colonial logra escapar del escrutinio del cura en la iglesia o del funcionario colonial en la urbe, a la vez que se reactiva y enriquecen los sistemas de inscripción de la memoria ancestral (grandes imágenes de geoglifos), con nuevos seres, interacciones e iconografías, en esta singular huaca que pasa a ser también un "espacio del anónimato" colonial.

En el arte rupestre colonial es habitual ver cruces cristianas superponiéndose a imágenes prehispánicas propiamente andinas (p.e., una cruz sobre un cóndor). Retomando la metáfora de Gruzinski, no cabe duda de que fue una verdadera "guerra de las imágenes" en una época en que Europa "ama a las imágenes, pero odia a los ídolos" y en la cual "las imágenes del adversario se vuelven intolerables cuando son imágenes de culto". La cruz fue el signo iconoclasta más característico de la colonia, o más precisamente, de "idoloclastía", dado que su propósito real era el "aniquilamiento sistemático de los ídolos” (Gruzinski 1994: 40). Con la superposición de la cruz cristiana se buscaba un doble propósito. Por un lado, servía para marcar como "lugares del diablo" los espacios que tuvieran inscripciones andinas o alguna relevancia ceremonial en el pasado prehispánico, estigmatizando de esta manera los lugares de las ancestrías locales y su historia profunda, tachándolos de idolátricos, demoníacos, paganos, superticiosos, prohibidos o censurados. La cruz simboliza todo lo que el nuevo orden colonial imponía olvidar, descontextualizar y transformar del pasado, en pos de "co-crear" una nueva historia que asegurara el sometimiento ideológico futuro a la Iglesia y a la Corona. Paradójicamente, la cruz además permitía limpiar, "descontaminar" y "convertir", al mismo tiempo, los lugares sagrados tradicionales en lugares evangelizados, mediante el extraño "reciclaje" de escenarios religiosos considerados paganos, pero rápidamente recuperados para el culto católico "mestizo". ${ }^{12}$

El geoglifo principal que hemos descrito, es la narración -en viaje- de un viaje segmentado en varias pequeñas escenas figurativas continuas, que están conectadas por medio de una gran escena que las representa caminando hacia el sur. Esta última escena se puede descomponer en cuatro micro-escenas temáticas, de norte a sur:

1) la caravana de llama y su depredador al "acecho" (imaginario e iconografía andina tradicional);

2) el "conquistador y el dragón” (imaginario e iconografía andino-europeos);

3) "jinete en cacería de taruca y arreo de burro" (imaginario andino-europeo e iconografía europea);

4) escena del "trompetista, los 10 bajo el madero, junto al diablo y San Miguel” (imaginario andino-europeo e iconografía europea).

La escena mayor se compone de dos ejes horizontales, cuyos giros están en correspondencia con las referidas micro-escenas. ${ }^{13}$ Podría ser parte de un sistema de comunicación y de codificación visual de relatos y "lecturas", que es precisamente lo que parece sugerir la imagen del Conquistador, dispuesto en otro plano dentro de la escena, más adelante, de frente y de grandes dimensiones, lo que le brinda una posición especialmente central dentro de la escena en general y, en particular, entre las micro-escenas 1 y 3 . La imagen del Conquistador trazada conforme a los cánones tardíos, parece responder a la necesidad de singularizar y resaltar a la nueva jefatura de acuerdo a los sistemas visuales andinos tradicionales de los períodos tardíos, vale decir, destacando los rasgos, indumentarias y centralidad de la autoridad y el poder. Además, se podrá reconocer en este caso que la figura del Conquistador es una notable ampliación de la imagen antropomorfa tardía, con dimensiones muy superiores a la figura ajedrezada Inka dentro del mismo panel, casi borrada, símbolo del imperio anterior.

Martínez y Martínez (2013) destacan que las pinturas en los queros coloniales deben ser entendidas como textos, con presencia de "micro-relatos" y en las cuales se materializaron distintos modos narrativos. Pensamos que la estructura y composición de la gran escena colonial recién analizada, amerita compararse con los igualmente figurativos dibujos de los queros coloniales. Aun cuando no se aprecian figuras como las que hemos descrito, hay en estos vasos representaciones de "micro-relatos" y ciertos tipos de composición similares a nuestro caso (p.e., en que el Conquistador 
separa distintos planos narrativos), que denotan la presencia de una estructura composicional y narrativa subyacente que podrían observarse en el geoglifo de la escena colonial. ${ }^{14}$

\section{SIGNIFICADOS Y NARRATIVAS DE LA ESCENA COLONIAL}

En este nivel de análisis, cabe preguntarse ¿cuál es el significado histórico de la escena del geoglifo colonial?, ¿con qué objetivo fue realizado? Proponemos cuatro hipótesis.

\section{La hipótesis histórica: ¿Almagro o Valdivia?}

Una primera hipótesis dice que la escena del geoglifo representa un evento histórico concreto: sea el paso hacia el Norte de las huestes de Almagro, de regreso de su fallida expedición a Chile, sea el de Pedro de Valdivia con su gente, yendo hacia el sur, cinco años después, rumbo a Atacama a tomar posesión de la Nueva Extremadura (Fernández de Oviedo 1901 [1557]: 251, Barros Arana 2004 [1884], nota 43: 159-160, Advis 2008: 164). ${ }^{15}$

Almagro salió de Cuzco mediando julio de 1535 con una numerosa hueste que se fue engrosando durante el trayecto, hasta contar con cerca de 20.000 hombres y mujeres, entre militares, caballeros, infantes españoles (ballesteros, arcabuceros y lanceros). El resto eran soldados incas o yanaconas entrenados para la guerra, aunque el contingente mayor estaba compuesto por servidores, cargadores y esclavos indígenas y africanos, junto a una enorme recua de llamas. En su desastroso retorno al Perú desde "Chile antiguo", Almagro decide volver por el camino "de los llanos" que va desde el actual valle de Copiapó y hasta el poblado de (San Pedro de) Atacama y de allí a (San Francisco de) Chiu-Chiu y Tarapacá. Así describe Barros Arana el viaje de regreso:

No hubo ni un solo español que no tomase algunos indios de servicio. Los que tenían cadenas, los amarraban con ellas; y los que no las tenían, hicieron fuertes sogas de cueros de guanaco para aprisionar a sus servidores por medio de cepos o lazos que los retenían por el cuello. Los indios cargaban los viveres, las ropas y las camas de los españoles, sin tener otro alimento que un poco de maíz tostado, y estaban obligados a andar sin descanso, atados en sartas de diez a doce individuos. Si uno de ellos enfermaba de extenuación y de fatiga durante la marcha, la sarta no se detenía por eso, y cuando moría alguno de estos infelices, le cortaban la cabeza para no abrir el candado de la cadena o para no deshacer el lazo; y dejando tirado el cadáver, la comitiva seguía su camino tranquilamente. Español hubo, dice un testigo de vista, que se alababa de que los doce indios de su sarta habían muerto de esa manera, sin dejarlos salir de la cadena (Barros 2004 [1884]: 48-49).

Nada se sabe de la llegada de Diego de Almagro desde Chiu Chiu a Tarapacá, puesto que las crónicas solo retoman sus andanzas en Arica, pero es probable que de Chiu-Chiu y Tamentica pasara al oasis de Pica y luego a Tarapacá, atravesando la Pampa del Tamarugal, con los ya no más de 300 españoles que lo acompañaban. Según Advis (2008), esa parte de la travesía del desierto se realizó entre principios del mes de noviembre y mediados del mes de diciembre del año de 1535. Las personas que llevan el "madero" perfectamente podrían ser esos sufrientes esclavos de la expedición almagrista, los ensartados y atados que describen los cronistas.

Pues bien, en los geoglifos de la Quebrada de Los Pintados coinciden elementos presentes en las crónicas de la expedición almagrista, por lo que no se puede descartar que estén conmemorando el terrible paso de Almagro, e incluso que sean contemporáneos al mismo, lo que entonces correspondería a la primera imagen de la hueste conquistadora que fuera grabada en el desierto.

\section{La hueste del Capitán Pedro de Valdivia rumbo a Nueva Extremadura}

Aunque la hipótesis almagrista no carece de fundamento, es más probable que, dada la orientación de los personajes hacia el camino que se abre hacia el sur de los geoglifos, que el panel corresponda al avance meridional de la expedición de la conquista de Chile de Pedro de Valdivia y su hueste en 1540: la alerta de guerra se encendió como reguero de pólvora hacia el sur de Tarapacá, entre los Picas y Caperuzones (Tarapacá) y luego entre los de Guatacondor y Atacama (Bibar 1966 [1538]: 12). ${ }^{16}$

El caso es que el Conquistador representado en los geoglifos de la Quebrada de Los Pintados podría ser Pedro de Valdivia. Su estatura dominante respecto de las demás figuras del panel, semejante a la del Diablo, expresa el temor inédito que debieron provocar el español y sus bestias. Los geoglifos pueden estar así, representando sintéticamente, tanto el paso de Valdivia como el de Almagro y los miles de esclavos que llevaban. 


\section{Castigar a idólatras trasladándolos a Santiago de Chile}

Alternativamente la escena podría estar dando cuenta del castigo y traslado de "falsos sacerdotes, hechiceros e idólatras" que, según los cronistas, solían ser trasladados a Santiago de Chile, donde eran recluidos, tal como describe el extirpador de idolatrías, Francisco Ávila, respecto de la condena recaída en el "falso sacerdote" Hernando Páucar en la plaza mayor de Lima, una tarde de diciembre de 1609. Los españoles quemaron "ídolos" y "cadáveres" (momias), mientras "en cada esquina se tocaban chirimías" y en un pasadizo amarraban a Páucar a un palo enhiesto, quitándole su manta y sombrero. Un notario leyó la sentencia: "200 azotes, quitarle el cabello y destierro perpetuo a Santiago de Chile, al colegio de la Compañía de Jesús" (Duviols 2012: 223). En su viaje a pie de Lima a Santiago, Páucar pudo ser uno de los que pasó, amarrado, por los senderos de Quebrada de Los Pintados y quizás, la escena colonial del geoglifo haya sido una representación del traslado por tierra de indígenas condenados por idolatría, hacia el Juicio Final.

\section{Una cuarta hipótesis endiablada}

Por último, una lectura de carácter más festiva y sagrada podría ver en el "madero" de la sarta de esclavos, una trompeta muy larga como las que se siguen empleando en diversas regiones del Perú, de hasta cinco metros de largo, conocido como Erque (Abancay) o Quepa (Cajamarca), las que se emplean también en Ayacucho y Apurimac (p.e., Civallero 2013), e incluso transformar a los mismos esclavos en danzantes de la tradicional Diablada, específicamente la de Oruro, y su épica oposición cosmogónica entre el bien y el mal, entre el Arcángel San Miguel y el Diablo. Así, la escena podría ser tanto una representación visual de la Diablada, como la de una peregrinación en la que se estuviera venerando alguna deidad andina en particular, como Wari o Tiw. Danzas, procesiones y música son ingredientes rituales de origen prehispánico persistentes en todo los Andes. Muchedumbres, proveniente de lugares a menudo muy distantes, acudían en procesiones y romerías a múltiples santuarios. ${ }^{17}$

La escena colonial de la Quebrada de Los Pintados Este no es una suma heteróclita de figuras individuales. Es más bien una obra unitaria que incluso puede estar integrando escenas de distintas épocas, un verdadero friso histórico de grandes dimensiones, que combina las técnicas del fresco renacentista con detalles de cada época, por medio de un verdadero mural o mosaico capaz de generar efectos de claroscuro, perspectiva y transparencia. Literalmente, aquí apenas hemos analizado el nivel más superficial de lectura, puesto que este fresco parece sobreponerse en parte a otros motivos prehispánicos, aún de de difícil reconocimiento, produciéndose un palimpsesto a explorar en el futuro.

Si consideramos además que Francisco Otal llevó adelante largos procesos de extirpación de idolatrías en Atacama y Lípez desde la vecina Chiu Chiu entre los años 1591 y 1645 (Hidalgo 2014) -cuando todavía no se delimitaba el corregimiento de Tarapacá-, es también posible que el geoglifo colonial haya sido realizado finalmente por esas mismas fechas, quizás como un intento simultáneo de reactivar las antiguas técnicas y políticas de la memoria, a la vez que "ocultar" o "adaptar" expresiones religiosas propiamente andinas, con personajes, indumentarias y adminículos de origen católico. Con todo, los resultados de nuestro trabajo indican que fueron construidos entre la segunda mitad del siglo XvI y finales del xvinI, y se produjo en las condiciones de un espacio nemotécnico tradicional, lejos de la mirada inquisidora de las autoridades coloniales.

Ciertamente, el sector elegido para levantar la escena colonial es más bien secundario, lateral y de baja visibilidad de la Quebrada de Los Pintados. Además, no se aprecian los rasgos propios de una acción extirpadora ejemplar. Aunque aún no determinamos el nivel de superposición con otras figuras preexistentes, es notable que el símbolo del Imperio Inka (la figura humana con vestimenta ajedrezada) no haya sido superpuesto por otros geoglifos. Aunque el contexto de la construcción de la escena puede haber sido el de la extirpación de idolatrías, la representación colonial en sí no sería el producto de dicho proceso, lo que explicaría el respeto que se mantuvo a los cientos de motivos prehispánicos diseminados por todo el área del sitio. La Quebrada de Los Pintados fue, al igual que Tamentica, un lugar altamente significativo en el imaginario prehispánico, el que fuera luego actualizado en la Colonia en el contexto probable de prohibiciones referentes a los lugares sacros andinos, cuando la iglesia católica y los conquistadores persiguieron la cosmovisión prehispánica, a sus cultores y a sus sistemas concretos de activación (Duviols 1977, Estenssoro 2003, Platt et al. 2006, Castro 2009, Hidalgo 2014). 
Ante todo, la escena representa en forma inigualable el choque cultural y biológico que significó la Conquista y las consecuencias en la formación, combinación y evolución heterógenea de algunas ideas, imágenes y rituales religiosos que prosiguen hasta hoy. Por eso, parafraseando a Bouysse-Cassagne (2004), podemos concluir que los conceptos de "sincretismo", "aculturación", "inculturación” o "mestizaje", usados generalmente para describir algunas de las dinámicas culturales que se llevaron a cabo en los Andes a raíz de la colonización, corresponden a una visión occidental binaria y, por lo tanto, muy simplista de la realidad, y no permiten describir lógicas y sensibilidades indígenas profundamente diferentes, como las asociadas monumentalmente a los geoglifos que hemos descrito. En efecto, estos geoglifos:

contradicen en definitiva una visión demasiado unívoca del sincretismo, de la pervivencia o de la adopción, porque constituyen un mosaico, compuesto de piezas algunas veces antagónicas, de prácticas y representaciones, fundadas hasta hace poco en una dialéctica de la ambivalencia y del acomodo (Bouysse-Cassagne 2004: 136).

\section{ENTRE HUACAS, DIABLOS, ÁNGELES Y DEMONIOS: PALABRAS FINALES}

En el imaginario andino de tiempo inmemorial, lugares como Quebrada de Los Pintados y Tamentica, debieron ser considerados importantes huacas (o Wak'a, guaca). Esto es, lugares, cosas o seres sagrados en lengua quechua, testimonio de una ontología con una profundidad temporal significativa en todos los Andes (BouysseCassagne 2004, Pimentel 2009, Brosseder 2014, Bray 2015, Nielsen et al. 2017).

La "memoria de los senderos" que recién empezamos a develar, nos ha permitido restituir parte de las prácticas nemotécnicas sobre lugares desérticos, inscritas como lugares sacros al menos desde el Período Formativo (ca. 1500 AC-500 DC) y para toda la secuencia prehispánica posterior, en que fueron ritualizados y remarcados en tanto huacas. La recurrencia de las imágenes inscritas refleja las reiteraciones propias del rito sacralizador, lo que al mismo tiempo se constituye como una "reserva" de memoria histórica, visual y social del mundo andino: desde Tunupa hasta San Miguel.

Sin embargo, la memoria de los senderos también ha sufrido fisuras, pérdidas y amnesias colectivas. Más allá de reconocerlos como "pintados que hacían los antiguos" y saber que por ahí iba el Camino del Inka, nadie sabe en los poblados cercanos cuál es el significado, temporalidad e importancia de este registro histórico único, aunque hoy la Comunidad Quechua de Huatacondo está empeñada en reactivar su valor patrimonial y nemotécnico. Puede que así las antiguas huacas andinas despierten de su prolongado letargo histórico, recuperando parte de su agencia y poder sobre los vivos (véase Gell 1998 y 1999 para una antropología de la agencia y el arte).

En contraste con el imaginario oficial, binario, históricamente desarraigado y colonizado que prevalece en Chile, los jóvenes huatacondinos están impregnados de la escena colonial, haciéndola propia, reconociendo con claridad al Diablo, a San Miguel, al Conquistador y a sus antepasados mismos, esclavizados. Así como les produce resquemor e impotencia el haber perdido gran parte del legado colectivo dejado por sus ancestros, quienes habitaron y recorrieron este desierto, dándole vida a la memoria de los senderos. Y por lo mismo nos insisten tanto en que sigamos investigando la arqueología e historia de su territorio, de modo que se pueda reactivar la memoria "extirpada" por la Conquista española, aquella que fue finalmente reemplazada por el otrora Nuevo Mundo Colonial, ese "mundo al revés" que se fraguó entre diablos, ángeles y endemoniados conquistadores. ${ }^{18}$

Agradecimientos Al Proyecto fondecyt 1181750. A la Comunidad Quechua de Huatacondo, especialmente a Mauricio y Manuel Hidalgo. Al equipo de la Fundación Desierto de Atacama, a Claudia Montero, Javier Arévalo, Juan Gili y Mariana Ugarte, quienes colaboraron con el registro, el levantamiento fotogramétrico y el dibujo técnico de los geoglifos. A Soledad González por su generosidad con varios datos etnohistóricos. A Constantino Torres, Álvaro Martel y los evaluadores por sus valiosas sugerencias y comentarios.

\section{NOTAS}

${ }^{1}$ Aquí ocupamos la forma aymara thaki tomada de Martínez (1976) y de Abercrombie (2006). A diferencia de otras versiones escriturales, en el diccionario de Bertonio (1612: 345) se escribe Thaqui, mientras Choque (2013) y Rivera Cusicanqui (2015) ocupan thakhi, y en la versión original inglesa de Abercrombie (1998) aparece como t"aki. Por otro lado, para una etnografía sobre la explicación quechua del mundo al andar, véase Cruz (2012). Sobre la conjunción entre los senderos de los humanos y los caminos de 
los soqos (vientos del oeste) en los relatos míticos aymara de Chipaya, ver Cereceda (2010).

${ }^{2}$ El mito de Tunupa es uno de los más ampliamente reconocidos en los Andes, especialmente en la zona Aymara donde es una de las deidades tradicionales principales. Cieza de León en 1550 lo describe como el "gran ordenador". En la mitología inka es el hijo rebelde de Viracocha. La relación Tunupa-Viracocha fue analizada por Wachtel (2001) y Bouysse-Cassagne (1997), quien ve en la configuración de ambas deidades la noción de Allqa, una relación interdependiente de oposición y complementariedad.

${ }^{3}$ Ramos Gavilán en 1621 describe la veneración que le profesaban a un sendero que se atribuía al paso de Tunupa desde Carabuco a Copacabana: "pasando por un totoral, dejó hecha una senda, la cual hasta hoy veneran los indios" (citado en Wachtel 2001: 511). Por otra parte, Bouysse-Cassagne (1997), considera que el "viaje acuático" de Tunupa podría estar influenciado por el relato Occidental de San Bartolomé, "el que cuelga agua". Consideramos que la correspondencia entre toponimia y el viaje mítico de Tunupa, no es una construcción programada en tiempos coloniales, sino que, rememorando a Cereceda (2010: 101), remite principalmente al "diseño de una mapa ecológico y geográfico", "un mito englobante, cuyo resultado es la imagen de un espacio".

${ }^{4}$ En la iglesia del pueblo de Carabuco, una serie pictográfica representa a Tunupa como San Bartolomé (Gisbert 2010, Siracusano 2010). Ver Absi (2003) y Bouysse-Cassagne (2004) sobre la evangelización de los Tataros (s. XIII).

${ }^{5}$ Para una descripción del proceso de alfabetización evangélica y sus efectos en Nueva España, ver Barros (2007).

${ }^{6}$ Clarkson y Briones (2001: 39, fig. 5) publicaron la sección inferior de esta escena, y parcialmente descrita previamente por Bellessort (1897). Lo que no se advirtió hasta ahora es que se trataba de una escena colonial. Aunque este sea el primer trabajo académico que lo publica íntegramente, ya lo habíamos dado a conocer en una charla pública realizada en el Museo Chileno de Arte Precolombino (noviembre 2015), y fue exhibida su fotogrametría en la exposición "Cuatro mil años de arte rupestre en el desierto de Antofagasta" (abril 2016). Se expuso también como gigantografía en estaciones del Metro de la ciudad de Santiago (septiembre 2017 a marzo del 2018), y se presentaron parte de las ideas aquí plasmadas en las Segundas Jornadas del Altiplano Sur (Tilcara, septiembre 2018).

${ }^{7}$ La figura también podría corresponder a un "león rampante", símbolo de la heráldica europea que llevaban los conquistadores en sus estandartes (el de Pizarro consistía en dos leones y dos cabezas de serpientes-dragones, véase Phipps 2004: 78, fig. 80), lo que no excluye la mencionada referencia a San Jorge y su dragón. Otra posibilidad es que se trate de alguna deidad andina, como la que representa Pachacuti Yamqui en el Coricancha como Chuquichinchay, el granizo, que es graficado como un felino al cual le salen de la boca varios apéndices lineales (rayos?) (Pachacuti Yamqui Salcamaygua (1993 [1613?]).
${ }^{8}$ André Bellessort describe así lo que vió en el camino a Huatacondo: "Más lejos se encuentran verdaderas pinturas que representan en sus formas geométricas tableros de ajedrez o de damas [...], las rampas de los cerros están ilustradas con dibujos. En ellos se ven rebaños de llamas conducidos por los Indios, bastón a la mano y a veces una tropa asustada que retrocede y vuelve la cabeza ante el espectáculo de un hombre ahorcado. La expresión de sorpresa y de pavor parece que está muy bien representada" (Bellessort 1897: 107).

${ }^{9}$ Dos zoomorfos amplían la escena: arriba del "trompetista” hay un cuadrúpedo que podría representar otro de los animales domésticos europeos como la oveja o el cerdo. En el otro extremo, el óvalo con una línea diagonal superior y dos apéndices inferiores podría representar al Suri (Rhea pennata tarapacensis).

${ }^{10}$ Los frescos coloniales hechos por artistas indígenas y mestizos en muchas iglesias andinas presentan también peculiaridades, transformaciones y arreglos singulares adaptados de los originales europeos (Gisbert 1980, Siracusano 2010).

${ }^{11}$ Considérense los siguientes estudios del arte rupestre colonial en los Andes: Gallardo et al. 1990, Hostnig 2003, Hernández Llosa 2006, Arenas \& Martínez 2009, Martínez \& Arenas 2009, González 2014, Arenas \& Odone 2015.

${ }^{12}$ Para esta interpretación nos basamos en los análisis de Gruzinski (1994: 48-50).

${ }^{13}$ Un eje de alineamiento $\left(40^{\circ} \mathrm{N}\right)$ va desde la figura de la llama de más al norte hasta el burro, mientras que el segundo eje $\left(10^{\circ} \mathrm{N}\right)$, se inicia desde el "trompetista" y va hasta la figura del Arcángel San Miguel.

${ }^{14}$ Sobre queros de la época Inka y Colonial, Cummins (2002) señala un tránsito entre las representaciones abstractas (Horizonte Inka) a las representaciones figurativas (Período Colonial). Martínez (2018) relativiza recientemente la supuesta evolución iconográfica de lo abstracto a lo figurativo. La historia visual de las imágenes figurativas prehispánicas indica que éstas surgen al menos desde el Período Arcaico Tardío, por lo que tiene una larga historia y temporalidad (Berenguer 2004b).

15 Sobre la autoridad inka e imágenes nemotécnicas, Guaman Poma narra que, estando en Ollantaytambo "mandó retratarse el dicho Mango Inga y a sus armas en una peña grandísima para que fuese memoria" (citado en Martínez \& Arenas 2015: 299).

${ }^{16}$ Aunque Advis (2008), basado en Cúneo Vidal (1977) supone que Almagro pasó de Chiu-Chiu a Quillagua siguiendo el curso del río Loa para cruzar luego la pampa del Tamarugal hacia Tamentica y Tarapacá, hay una ruta mucho más corta que bien pudo ser la que utilizaron tanto Almagro como Valdivia en sentido contrario: Chiuchiu-Santa Bárbara-Torruno-Quebrada de Chala-Cuno-Quegüita-Maní-Tamentica (Bertrand 1885: 261).

${ }^{17}$ Por ejemplo, en 1570 el ídolo Tata Porco era resguardado por Diego Iquisi (punku kamayuk, portero de wak'a), 
atraía a peregrinos de Cochabamba y de toda la Provincia de Charcas, Caracaras, Yamparaes, Chichas, Yuras, Visisas, Asanaques, Carangas y Chuyes (Abercrombie 1998: 267).

${ }^{18}$ Tomamos la frase "mundo al revés" del análisis que hace Rivera Cusicanqui (2015) de la obra de Guaman Poma, a partir del cual se caracteriza a la Colonia como ese "mundo al revés", aún no superado.

\section{REFERENCIAS}

Abercrombie, T. A. 1998. Pathways of memory and ower. Ethnography and history among an Andean people. Wisconsin: The University of Wisconsin Press.

Abercrombie, T. A. 2006. Caminos de la memoria y del poder: etnografía e historia en una comunidad andina. La Paz: Instituto de Estudios Bolivianos-IFEA.

AвsI, P. 2003. Les ministres du diable. Le travail et ses représentations dans les mines de Potosi, Bolivia. París: L'Harmattan.

Advis, P. 2008. El desierto conmovido. Paso de la hueste de Almagro por el norte de Chile. Iquique: Universidad Arturo Prat.

Arenas, M. \& Martínez, J. L. 2009. Construyendo nuevas imágenes sobre los otros en el arte rupestre andino colonial. Revista Chilena de Antropología Visual 13: 17-36.

Arenas, M. \& Odone, M. C. 2015. Cruz en la piedra. Apropiación selectiva, construcción y circulación de una imagen cristiana en el arte rupestre andino colonial. Estudios Atacameños 51: 137-151.

BARros, A. 1997. Desarrollo y pachamama: paisajes conflictivos en el desierto de Atacama. Estudios Atacameños 13: 75-94.

BARros, A. 2007. Cien años de guerras mixes: territorialidades prehispánicas, expansión burocrática y zapotequización en el Istmo de Tehuantepec durante el siglo Xvi. Historia Mexicana 57 (2): 1131-1133.

Barros, D. 2004 [1884]. Historia general de Chile. Tomo I. Santiago: Universitaria.

Bellessort, A. 1897. Jeune Amérique. París: Perrin et Cie.

BERENGUER, J. 2004a. Tráfico de caravanas, interacción interregional y cambio cultural en la prehistoria tardía del desierto de Atacama. Santiago: Sirawi.

Berenguer, J. 2004b. Cinco milenios de arte rupestre en los Andes atacameños: imágenes para lo humano, imágenes para lo divino. Boletín del Museo Chileno de Arte Precolombino 9: 75-108.

Berenguer, J. 2013. Unkus ajedrezados en el arte rupestre del sur del Tawantinsuyu: ¿la estrecha camiseta de la nueva servidumbre? En Las tierras altas del área Centro Sur Andina entre el 1000 y el 1600 DC, M. E. Albeck, M. Ruiz \& M. B. Cremonte, Eds., pp. 311-532. San Salvador de Jujuy: Universidad Nacional de Jujuy.

Berenguer, J. \& Pimentel, G. 2017. Introducción al estudio de los espacios internodales y su aporte a la historia, naturaleza y dinámica de las ocupaciones humanas en zonas áridas. Estudios Atacameños 56: 3-11.
Bernand, C. \& Gruzinski, S. 1993. Histoire du Nouveau Monde. París: Fayard.

Bertonio, L. 1612. Vocabulario de la lengua aymara. Chucuito: Compañía de Jesús de Juli.

Bertrand, A. 1885. Memoria sobre las cordilleras del desierto de Atacama i rejiones limitrofes. Santiago: Imprenta Nacional.

BIBAR, G. de, 1966 [1538]. Crónica y relación copiosa y verdadera de los Reynos de Chile hecha por... natural de Burgos. Santiago: Fondo Histórico y Bibliográfico José T. Medina.

Bouysse-Cassagne, T. 1997. De Empédocles a Tunupa: evangelización, hagiografía y mitos. En Saberes y memorias en los Andes: homenaje a Thierry Saignes, T. BouysseCassagne, Ed., pp. 151-206. Lima: Instituto Francés de Estudios Andinos.

Bouysse-CAssagne, T. 2004. El sol de adentro: wak' as y santos en las minas de Charcas y en el lago Titicaca, siglos Xv a XVII. Boletín de Arqueología PUCP 8: 59-97.

Bouysse-Cassagne, T. 2008. Le diable en son royaume. Evangélisation et images du diable dans les Andes. Terrain 50: 124-139.

BRAY, T. (Ed.). 2015. The archaeology of wak'as. Explorations of the sacred in the pre-columbian Andes. Colorado: University Press of Colorado.

Briones, L. 2006. The geoglyphs of the north Chilean desert: an archaeological and artistic perspective. Antiquity 80: 9-24.

Briones, L., Núñez. L. \& Standen, V. 2005. Geoglifos y tráfico prehispánico de caravanas de llamas en el desierto de Atacama (norte de Chile). Chungara 37 (2): 195-223.

Brosseder, C. 2014. The power of huacas. Change and resistance in the Andean world of colonial Peru. Texas: The University of Texas Press.

Cabello, G. \& Gallardo, F. 2014. Íconos claves del Formativo en Tarapacá (Chile): el arte rupestre de Tamentica y su distribución regional. Chungara 46 (1): 11-24.

Castro, V. 2009. De ídolos a santos. Evangelización y religión andina en los Andes del sur. Santiago: Fondo de Publicaciones Americanistas Universidad de Chile-Centro de Investigaciones Barros Arana.

Cereceda, V. 2010. Una extensión entre el altiplano y el mar. Relatos míticos chipaya y el norte de Chile. Estudios Atacameños 40: 101-130.

Chacama, J. \& Espinosa, G. 1997. La ruta de Tarapacá: análisis de un mito y una imagen en el norte de Chile. En Actas del XIV Congreso Nacional de Arqueología Chilena 1, pp. 769-792. Copiapó: Museo Regional de Atacama.

Choque, C. 2013. "Amt'añ thakhi” en Socoroma: significado y expresiones del uso de la memoria en una comunidad aymara del norte de Chile. Confluenze 5 (1): 136-157.

Civallero, E. 2013. Las trompetas largas de los Andes. Revista Miradero 5: 5-14.

Clarkson, P. \& Briones, L. 2001. Geoglifos, senderos y etnoarqueología de caravanas en el desierto chileno. Boletín del Museo Chileno de Arte Precolombino 8: 35-45. 
Corti, P., Guzmán, F. \& Pereira, M. 2013. La pintura mural de Parinacota, en el último bofedal de la Ruta de la Plata. Arica: Fundación Altiplano-Universidad Adolfo Ibáñez.

Cruz, P. 2012. El mundo se explica al andar. Consideraciones en torno a la sacralización del paisaje en los Andes del sur de Bolivia (Potosí, Chuquisaca). Indiana 29: 221-251.

Cummins, T. 2002. Toasts with the Inca: andean, abstraction and colonial images on quero vessels. Michigan: The University of Michigan Press.

Cúneo Vidal, R. 1977. Obras completas. Lima: Gráfica Morsom.

Duviols, P. 1977. La destrucción de las religiones andinas (durante la Conquista y la Colonia). México: Universidad Nacional Autónoma de México.

Duviols, P. 2012. Estudio bibliográfico de Francisco de Ávila, extirpador de la idolatría. En Dioses y hombres de Huarochirí. Narración quechua recogida por Francisco de Avila (¿1598?). Lima: Instituto de Estudios Peruanos.

Estenssoro, J. C. 2003. Del paganismo a la santidad. La incorporación de los indios del Perú al catolicismo. Travaux de l'IfeA, 156. Lima: Institut Français d'Études AndinesInstituto Riva Agüero.

Fernández de Oviedo, G. 1901 [1557]. Historia general y natural de las Indias Isla y tierra firme del mar océano. Colección de Historiadores de Chile, tomo xxvir. Santiago: Imprenta Elzeviriana.

Gallardo, F., \& Cabello, G. 2015. Emblems, leadership, social interaction and early social complexity: the Ancient Formative Period (1500 BC-100 AD) in the desert of northern Chile. Cambridge Archaeological Journal 25 (3): 615-634.

Gallardo, F., Castro, V. \& Miranda, P. 1990. Jinetes sagrados en el desierto de Atacama. Un estudio de arte rupestre andino. Boletín del Museo Chileno de Arte Precolombino 4: 27-56.

Gallardo, F., G. Cabello \& G. Pimentel. 2018. Signs in the desert: geoglyphs as cultural system and ideology (northern Chile). En Archaeologies of rock art: south american perspectives, A. Troncoso, F. Armstrong \& G. Nash, Eds., pp. 130-149. Nueva York: Routledge.

Gell, A. 1998. Art and agency: an anthropological theory. Oxford: Oxford University Press.

GeLl, A. 1999. The art of anthropology: essays and diagrams. Eric Hirsch, Ed. Londres: London School of Economics monographs on social anthropology, BERG.

GISBERT, T. 1980. Iconografía y mitos indígenas en el arte. La Paz: Gisbert y Cía.

Gisbert, T. 1998. Pintura mural en el área centro sur andina. La Paz: Ministerio de Educación, Cultura y DeporteOrganización de los Estados Americanos.

GisBert, T. 2010. El cielo y el infierno en el mundo virreinal del sur andino. En La paleta del espanto. Color y cultura en los cielos e infiernos de la pintura colonial andina, G. Sircausano, Ed., pp. 15-30. Buenos Aires: UnsAm EDITA. GonZÁlez, B. 2014. Discursos en el paisaje andino colonial: reflexiones en torno a la distribución de sitios con arte rupestre colonial en Tarapacá. Diálogo Andino 44: 75-87.

Guzmán, F., Corti, P. \& Pereira, M. 2017. Política eclesiástica y circulación de ideas tras las pinturas murales realizadas durante el siglo xviı en las Iglesias de la ruta de la Plata. Historia 50 (II): 525-554.

GruZinski, S. 1994. La guerra de las imágenes. De Cristóbal Colón a "Blade Runner" (1492-2019). México: Fondo Cultura Económica.

Неснт, J. 2004. The past is present: transformation and persistence of imported ornament in Viceregal Peru. En The colonial Andes. Tapestries and silverwork, 1530-1830, E. Phipps, J. Hecht \& C. E. Martín, Eds., pp. 42-71. Nueva York: The Metropolitan Museum of Art.

HERNÁNDEZ, M. I. 2006. Inkas y españoles a la conquista simbólica del territorio Humahuaca: sitios, motivos rupestres y apropiación cultural del paisaje. Boletín del Museo Chileno de Arte Precolombino 11(2): 9-34.

Hidalgo, J. 2014. Redes eclesiásticas, procesos de extirpación de idolatrías y cultos andinos coloniales en Atacama. Siglos XVII y XVIII. En Historia andina en Chile. Políticas imperiales, dinámicas regionales y sociedades indígenas, J. Hidalgo, Ed., Volumen II, pp. 183-237. Santiago: Universitaria.

Hostnig, R. 2003. Arte rupestre del Perú. Inventario nacional. Lima: CONCYTEC-UNMSM.

Martínez, G. 1976. El sistema de los uywiris en Isluga. En Homenaje al Dr. R. P. Gustavo Le Paige, L. Núñez, Ed., pp. 255-327. Antofagasta: Universidad del Norte.

Martínez, G. 1983. Los dioses de los cerros en los Andes. Journal de la Société des Américanistes 69: 85-116.

MartíneZ, J. L. 2009. Registros andinos al margen de la escritura: el arte rupestre colonial. Boletín del Museo Chileno de Arte Precolombino 14 (1): 9-35.

MARTíneZ, J. L. 2018. Los sistemas andinos de comunicación durante los períodos incaico y colonial: el caso de los queros. En Interpretando huellas. Arqueología, etnohistoria y etnografía de los Andes y sus tierras bajas. M. A. Muñoz, Ed., pp. 447-467. Cochabamba: Kipus.

Martínez, J. L. \& Arenas, M. 2009. Problematizaciones en torno al arte rupestre colonial en las áreas Centro Sur y Meridional Andina. En Crónicas sobre la piedra. Arte rupestre de las Américas, M. Sepúlveda, L. Briones \& J. Chacama, Eds., pp. 129-140. Arica: Universidad de Tarapacá.

Martínez, J. L \& Arenas, M. 2015. Iglesia en la piedra: representación rupestre y evangelización en los Andes del sur. La vitalidad de las voces indígenas. Arte rupestre del contacto y en sociedad coloniales, F. Berrojalbiz, Ed., pp. 299-325. México: UnAM.

Martínez, J. L. \& Martínez, P. 2013. Narraciones andinas coloniales. Oralidad y visualidad en los Andes. Journal de la Société des Américanistes 99 (2): 41-81.

Mebold, L. 1987. Catálogo de pintura colonial en Chile. Obras en monasterios y conventos de religiosas de antigua fundación. Santiago: Universidad Católica de Chile. 
Medinacelli, X. 2012. Bertonio y el mito de Tunupa. Ciencia y Cultura 28: 133-151.

Milla, C. 2011. Génesis de la Cultura Andina. Lima: Amaru Wayra.

Money, M. 1983. Los obrajes, el traje y el comercio de ropa en la Audiencia de Charcas. La Paz: Instituto de Estudios Bolivianos.

MontT, I. 2005. Vestimenta en la cultura visual tardía del desierto de Atacama. Tesis para optar al título profesional de Arqueóloga, Universidad de Chile, Santiago.

Mostny, G. 1970. La subárea arqueológica de Guatacondo. Boletín del Museo Nacional de Historia Natural 16: 271-289.

Muchembled, R. 2002. Historia del diablo. Siglos XII-XX. México: FCE.

Murra. J., Wachtel, N. \& Revel, J. (Eds.). 1986. Anthropological history of Andean polities. Cambridge: Cambridge University Press.

NieLSEN, A. 2007. Armas significantes: tramas culturales, guerra y cambio social en el sur andino prehispánico. Boletín del Museo Chileno de Arte Precolombino 12 (1): 9-41.

Nielsen, A., Angiorama, C. \& Ávila, F. 2017. Ritual as interaction with non-humans: prehispanic mountain pass shrines in the Southern Andes. En Rituals of the past. Prehispanic and colonial case studies in Andean archaeology, S. Rosenfeld \& S. Bautista, Eds., pp. 241-266. Colorado: University Press of Colorado.

NúÑEZ, L. 1976. Geoglifos y tráfico de caravanas en el desierto chileno. En Homenaje al Dr. R. P. Gustavo Le Paige, L. Núñez, Ed., pp. 147-201. Antofagasta: Universidad del Norte.

Pachacuti Yamqui Salcamaygua, J. S. C. 1993 [1613?]. Relacion de antiguedades deste Reyno del Piru., P. Duviols \& C. Itier, Eds. Lima: Institut français d'études andines-Centro de estudios Regionales Andinos Bartolomé de las Casas.

Phipps, E. 2004. Cumbi to tapestry: collection, innovation and transformation of the colonial Andean tapestry tradition. En The colonial Andes. Tapestries and silverwork, 1530-1830, E. Phipps, J. Hecht \& C. E. Martín, Eds., pp. 72-99. Nueva York: The Metropolitan Museum of Art.

Pimentel, G. 2009. Las huacas del tráfico. Arquitectura ceremonial en rutas prehispánicas del desierto de Atacama. Boletín del Museo Chileno de Arte Precolombino 14 (2): 9-38.

Pimentel, G. 2011. Geoglifos e imaginarios sociales en el desierto de Atacama (Región de Antofagasta, Chile). En Temporalidad, interacción y dinamismo cultural. La búsqueda del Hombre. Homenaje al Profesor Lautaro Núñez Atencio, A. Hubert, J. A. González \& M. Pereira, Eds., pp. 163-200. Antofagasta: Universidad Católica del Norte.

Pimentel, G., Ugarte, M., Gallardo, F., Blanco, J. \& MonTERo, C. 2017. Chug-Chug en el contexto de la movilidad internodal prehispánica en el desierto de Atacama, Chile. Chungara 49 (4): 483-510.

Ponce SAnginés, C. 1969. Tunupa y Ekeko. Estudio arqueológico acerca de las esfigies precolombinas de dorso adunco. Cochabamba-La Paz: Los Amigos del Libro.
Platt, T. 1980. Espejos y maíz: el concepto de yanantin entre los macha de Bolivia. En Parentesco y matrimonio en los Andes, E. Mayer \& R. Bolton, Eds., pp. 139-183. Lima: Pontificia Universidad Católica del Perú.

Platt, T., Bouysse-Cassagne, T. \& Harris, O. 2006. Qaraqara-Charka. Mallku, Inka y rey en la provincia de Charcas (siglos XV-XVII). Historia antropológica de una confederación aymara. La Paz: IFEA-Plural-University of St. Andrews-University of London.

Rivera, M. 2005. Arqueología del desierto de Atacama: la etapa formativa en el área de Ramaditas/Guatacondo. Santiago: Universidad Bolivariana.

Rivera Cusicanqui, S. 2015. Sociología de la imagen. Miradas ch'ixi desde la historia andina. Buenos Aires: Tinta Limón.

Rodríguez, A. \& Etchelecu, L. 2010. El abismo de los sentidos: el infierno de Carabuco y la prédica sobre las postrimerías. En La paleta del espanto. Color y cultura en los cielos e infiernos de la pintura colonial andina, G. Sircausano, Ed., pp. 33-53. Buenos Aires: UnSAM EdiTA.

Rosenfeld, S. A. \& S. Bautista. 2017. Rituals of the past. Prehispanic and colonial case studies in Andean archaeology. Colorado: University Press of Colorado.

Rostworowski, M. 1983. Estructuras andinas del poder: ideología religiosa y política. Lima: Instituto de Estudios Peruanos.

Siracusano, G. 2010. Notas para detener el "escándalo": fiesta, color e idolatría en el Virreinato del Perú. En La paleta del espanto. Color y cultura en los cielos e infiernos de la pintura colonial andina, G. Sircausano, Ed., pp. 97-109. Buenos Aires: UnSAM EDITA.

Urbano, H. 1988. Thunupa, Taguapaca, Cachi. Introducción a un espacio simbólico andino. Revista Andina 6: 201-224.

Urbina, S., Adán, L. \& Pellegrino, C. 2012. Arquitecturas formativas de las Quebradas de Guatacondo y Tarapacá a través del proceso aldeano (ca. 900 AC-1000 DC). Boletín del Museo Chileno de Arte Precolombino 17 (1): 31-60.

URIBE, M. \& VidAL, E. 2012. Sobre la secuencia cerámica del Período Formativo de Tarapacá (900 AC-900 DC): estudios en Pircas, Caserones, Guatacondo y Ramaditas, norte de Chile. Chungara 44 (2): 209-245.

Urton, G. 1981. At the crossroads of the earth and the sky: an Andean cosmology. Austin: University of Texas Press.

Valenzuela D., Santoro, C. \& Briones, L. 2011. Arte Rupestre, tráfico e interacción social: cuatro modalidades en el ámbito exorreico de los valles occidentales, norte de Chile (Períodos Intermedio Tardío y Tardío, ca. 10001535 DC). En En Ruta. Arqueología, historia y etnografía del tráfico sur andino, L. Núñez \& A. Nielsen, Eds., pp. 199-245. Córdoba: Encuentro.

WACHTEL, N. 2001. El regreso de los antepasados. Los indios urus de Bolivia, del siglo Xx al XVI. Ensayo de historia regresiva. México: Fondo de Cultura Económica. 